\title{
LAS MUSAS JONIAS APRENDEN A ESCRIBIR: LEY ESCRITA Y TRATADO EN PROSA EN LOS MILESIOS Y HERÁCLITO*
}

\author{
Raúl CABALlero \\ Universidad de Málaga \\ THE IONIAN MUSES LEARN TO WRITE: WRITTEN LAW \\ AND PROSE TREATISE IN THE MILESIANS AND HERACLITUS
}

A lo largo del s. VI a. C., los primeros investigadores jonios de la naturaleza escogieron como medio de expresión un procedimiento hasta entonces prácticamente inexplorado: la escritura en prosa. Esta tecnología se había probado antes sólo en el terreno de la legislación escrita de las ciudades, que recurría a enormes inscripciones en piedra para dar publicidad a las leyes y normativas de la comunidad. Esta publicidad servía además para sancionar con la firmeza de lo perdurable la autoridad cívica de la que emanaba una ley de obligado cumplimiento.

En este trabajo, intentamos mostrar que los modos de producción y publicación de las leyes sirvieron en cierta medida a los primeros filósofos como modelos de referencia para la publicación
Throughout s. VI B. C., the first Ionic investigators of the nature chose as way of expression a procedure practically unexplored at that time: the writing in prose. This technology had been only proved previously in the field of the cities written legislation, which liked to use enormous stone inscriptions to show or advertise the laws and community regulations. This publicity was also good to reinforce with the strenght of the lasting thing the civic authority, from which emanated a compulsory law to be carried out.

In this work, we try to show that the production and publication ways of the laws were good in certain extent to the first philosophers as reference models for the publication of their own treatises in

\footnotetext{
* Como el lector puede comprobar, la primera parte del título de este artículo es un calco del título del magnífico libro de E. A. Havelock 1996, donde el autor sintetiza los resultados más importantes de sus investigaciones en el campo de la oralidad y la escritura desde finales de los años cincuenta del siglo XX. La única modificación ("Las Musas jonias..." en lugar de "La Musa...") viene exigida por la necesidad de adaptar el título al libro de Heráclito, al que Platón se refiere con un elíptico "ciertas Musas de Jonia" en Soph. 242d y que, según Diógenes Laercio (IX 12, quizá siguiendo a Platón), había recibido en la Antigüedad, entre otros títulos, el de Musas.
} 


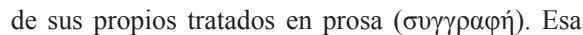
publicación existió sin duda, pero no fue exigida principalmente por una demanda lectora, sino que perseguía revestir el mensaje encerrado en el rollo de papiro con la autoridad asociada a la promulgación escrita de las leyes. Se trataba, pues, de un gesto simbólico de mediación entre el filósofo y la ciudad: al equiparar su obra a la ley de la ciudad, aquél reivindicaba la fuerza normativa y universal del cosmos descrito en el tratado en prosa, que enunciaba leyes válidas para todos los hombres y en todas partes. En este trabajo, exploraremos esta hipótesis estudiando el trasfondo sociopolítico que se perfila tras la publicación de los tratados de Anaximandro, Anaxímenes y, sobre todo, Heráclito. La ofrenda del libro de Heráclito al templo de Ártemis en Éfeso puede ser interpretada desde esta nueva perspectiva.

Palabras clave: Presocráticos; tratado en prosa; Anaximandro; Heráclito; legislación en las ciudades arcaicas; Jonia en el siglo VI a. C.

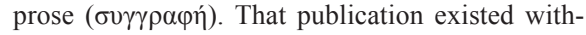
out a doubt, but it was not claimed by a demand reader mainly, but rather it pursued to reinforce the message locked in the papyrus roll with the authority associated to the written promulgation of the laws. It was, threrefore, a question of symbolic mediation between the philosopher and the city: comparing their work to the law of the city, he claimed the normative and universal force from the cosmos described in the treatise in prose, that enunciated valid laws for all the men and everywhere. In this work, we will explore this hypothesis studying the sociopolitical background that is outlined after the publication of the treatises of Anaximander, Anaximenes and, mainly, Heraclitus. The offering of Heraclitus book to the temple of Artemis in Ephesus can be interpreted from this new perspective.

Keywords: Presocratics; prose treatise; Anaximander; Heraclitus; laws in archaic cities; Ionia, s. VI B. C.

En la Jonia del siglo VI a. C., la publicación de los primeros tratados en prosa de los presocráticos obedeció no tanto a la demanda de un público lector, entonces casi inexistente, cuanto a un cierto mimetismo de lo que significaba en las ciudades arcaicas la promulgación y exhibición pública de las leyes. La fuerza normativa de la ley, la autoridad de sus prescripciones dependían simbólicamente de la visibilidad de los textos legales, que se publicaban, sobre imponentes inscripciones de piedra, en edificios civiles y religiosos de la polis ${ }^{1}$. La lectura de los textos legales inscritos en piedra no era el fin inmediato de su publicación; ésta por sí sola señalaba la fuente de la autoridad cívica y sancionaba el carácter normativo y obligatorio de su cumplimiento. Los primeros tratados en prosa de los pensadores jonios no podían aspirar desde luego a esa presencia ubicua de los textos legales; en su lugar, fueron confiados al formato del rollo de papiro, por pocas que fuesen sus copias, y puestos a disposición de un grupo social o una comunidad política, para que pudieran ser leídos en público o memorizados o reutilizados en investigacio-

1 M. Detienne 1989b (1988), pp. 10-21; R. Thomas 1992, pp. 65-73; K.-J. Hölkeskamp 1992, pp. 99-102; M. Gagarin 2003, pp. 59-77. 
nes posteriores. Pues bien, al hacer esto, que es lo que podemos considerar "publicación” en la Grecia Arcaica, los primeros prosistas jonios perseguían, con medios más modestos, fines simbólicos similares a los que guiaban la pu-

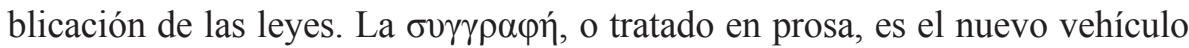

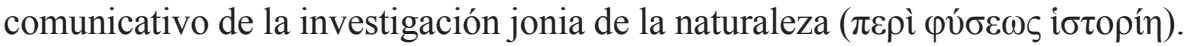

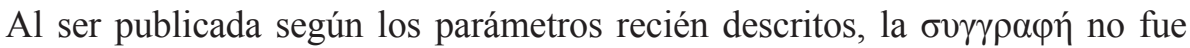
sólo un soporte subsidiario de la exhibición oral, como los textos de la poesía, ni ofreció sin más un instrumento de lectura para un público más o menos abstracto, todavía en ciernes, sino que aspiraba a petrificarse de inmediato como la expresión lapidaria de una ley universal y de un orden cósmico regido por normas tan coactivas como las de la ciudad. La prosa filosófica primitiva nació en estrecho diálogo con la prosa jurídico-legal de la polis, como demuestra la notable influencia del lenguaje jurídico-político de las ciudades griegas en los modos de expresión de los primeros filósofos jonios ${ }^{2}$.

Además, como es natural, el procedimiento de la publicación era quizá el medio más eficaz que tenían a su alcance los prosistas primitivos para que los escritos que compusieron perdurasen a través del tiempo. En esta nueva forma literaria, en efecto, no había garantía de transmisión oral consistente y segura, que cumpliera una función equivalente a la actividad secular de los cantores épicos profesionales, y mantuviera así la memoria colectiva de unas investigaciones que eran consideradas por sus autores tanto o más fuertemen-

2 Con esto queremos decir que, en cierto modo, uno de los paradigmas comunicativos más importantes de la prosa jonia primitiva fueron los textos legales. Es evidente que la poesía épica tradicional ejerció también su influencia en algunos conceptos jurídicos "mitologizados" de los milesios y Heráclito (Justicia, Zeus, Erinias, etc.), así como en ciertos rasgos de estilo (el estilo "oracular" de Heráclito, por ejemplo, bebía de la poesía oracular en hexámetros). De todos modos, como veremos en el curso de este artículo, tales pensadores trataron de distanciarse críticamente de los modelos literarios suministrados por los géneros poéticos tradicionales y se internaron en el nuevo experimento de la prosa, hasta entonces sólo explorado por las leyes escritas, para ofrecer una explicación integral y unitaria del universo que pudiese competir con la imagen cósmica de los poetas. A diferencia de los jonios, algunos poetas filósofos de Occidente (Parménides de Elea y Empédocles de Agrigento, pero también Jenófanes de Colofón, que desarrolló su profesión de rapsoda itinerante sobre todo en la Magna Grecia), prefirieron anclar sus creaciones literarias en la tradición épica de los griegos (ya fuera homérica o religiosa, como ciertos poemas órficos). Si el modelo de la prosa legal sitúa el pensamiento de los filósofos jonios en medio del debate político y ético de sus ciudades, no menor es la resonancia que el género épico presta a la filosofía de Parménides y Empédocles. Es problemático decidir (y no es el objeto de este artículo) si estas diversas estrategias comunicativas obedecen a una cierta heterogeneidad del medio socio-cultural (Jonia y la Magna Grecia) en el que se produjeron esas obras. Sobre esta cuestión, cf. A. Bernabé 1979, pp. 369-380. 
te normativas que las leyes de las ciudades, al enunciar leyes universales y válidas para todos los hombres ${ }^{3}$. Es precisamente gracias a la asociación simbólica entre la escritura publicada del tratado en prosa y la fuerza normativa de la ley pública de la polis como se fue formando una tradición escrita en prosa, que atesoraba los testimonios culminantes del espíritu de investigación desplegado en el mundo jonio a lo largo del siglo VI a. C. ${ }^{4}$

Pero, si nuestra hipótesis es plausible, sólo podrá evaluarse convenientemente si desarrollamos la premisa en que se basa - la relación semiótica

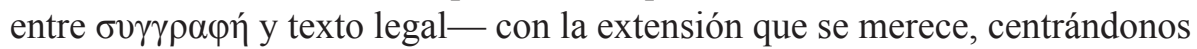
en los sabios jonios que en sus fragmentos nos han dejado más indicios de esa ambición normativa: Anaximandro, Anaxímenes y Heráclito. En esta tarea, se abre un doble camino: a) interrogar a los propios fragmentos que conservamos de estos autores, rastreando en su lenguaje y pensamiento huellas ciertas de la prosa legal contemporánea ${ }^{5}$; b) contextualizar su mensaje en el horizonte histórico y cultural de las ciudades jonias en las que fueron publicados los primeros tratados en prosa: Mileto y Éfeso entre la segunda mitad del s. VI y la primera mitad del siglo V a. C. Este segundo aspecto será el objetivo del presente artículo.

${ }^{3}$ En los últimos años, han visto la luz estudios que inciden en esta idea de la interrelación entre las leyes de las ciudades arcaicas y la fundación de una prosa filosófica en Jonia: cf. A.Laks 2001 (en el caso de Ferécides de Siro), M. Asper 2004, M. ${ }^{a}$ M. Sassi 2006 (en el caso de Anaximandro). Como intentamos probar en este trabajo, nosotros estamos convencidos de la pertinencia de aplicar este hallazgo al terreno de la publicación y transmisión de los primeros tratados en prosa (sobre todo, el de Heráclito). Para L. Rossetti 2006, en fin, sería posible

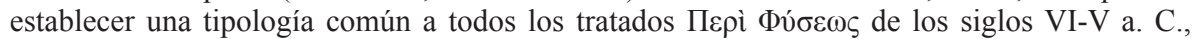
tanto en prosa como en verso.

4 Ofrezco en este prólogo una apretada síntesis de las conclusiones de dos trabajos (R. Caballero 2005a, 2005b), donde analizo con detalle los problemas relativos a la publicación de los primeros tratados en prosa en el contexto de la cultura jonia arcaica. La tesis que en este artículo tratamos de desarrollar está ya sugerida, en forma de símil, por W. Jaeger $1962^{2}\left(1936^{2}\right)$, p. 154; de ella se hacen eco también J. P. Vernant 1986 (1962), p. 41 s., y, en el caso particular de Heráclito, J. N. Bremmer 1994, p. 32. De forma independiente a nuestras investigaciones, M. ${ }^{a}$ Michela Sassi ha establecido también un paralelismo muy estrecho entre la escritura de la ley y la escritura de los primeros tratados en prosa, con ejemplos tomados de fuentes epigráficas. Se trata de un estimulante trabajo (M. ${ }^{a}$ M. Sassi 2006, pp. 3-26), publicado posteriormente a los míos, pero que recoge el contenido de una ponencia presentada en 2004.

5 Esta primera aproximación al problema la hemos realizado en un estudio («Ley escrita y tratado en prosa: el mundo conceptual de la polis en la cosmología de Anaximandro y Heráclito») que está en curso de publicación en las Actas del I Congreso Internacional de Filosofía Griega, celebrado entre el 24 y 26 de abril de 2008 en Palma de Mallorca bajo los auspicios de la Sociedad Ibérica de Filosofia Griega. 


\section{Los milesios: Anaximandro y Anaxímenes}

1. Los estudios clásicos de Jaeger y las investigaciones más recientes en torno al fr. B1 de Anaximandro ${ }^{6}$ han demostrado con creces que, en ese texto, los conceptos forjados para la descripción de las leyes cósmicas que rigen los procesos naturales están tomados del vocabulario judicial, moral y político de las ciudades arcaicas ${ }^{7}$. La generación y destrucción recíprocas de

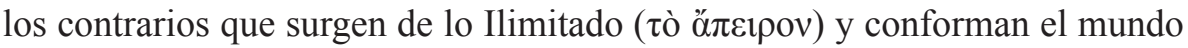
(lo frío y lo caliente, lo húmedo y lo seco), son descritas como una lucha

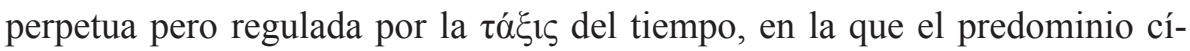
clico y alternativo de cada uno de los contrarios sobre los restantes no es ni "inocente" ni duradero, sino que ha de ser compensado por la pena de sufrir el predominio sucesivo a manos de los demás.

¿A qué sociedad iba destinado este mensaje de lucha sin cuartel, pero autosostenida, entre contrarios? ¿Y cómo se articulaba esa enseñanza? El libro de Anaximandro, según nuestras fuentes doxográficas, fue escrito «en el segundo año de la 58. a Olimpíada, cuando su autor tenía 64 años» (es decir,

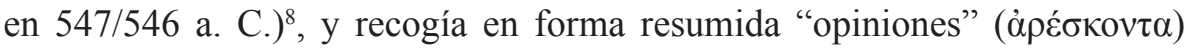
más o menos estructuradas sobre el origen del mundo (cosmogonía) y de la vida animal, el orden geométrico del universo (cosmología), los fenómenos celestes (meteorología) y la extensión y poblamiento de la tierra habitada

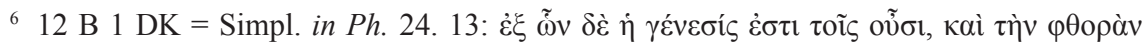

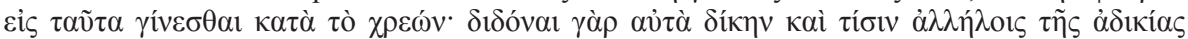

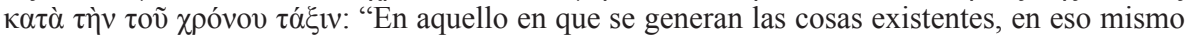
vienen a destruirse, según necesidad; pues se pagan unas a otras pena y retribución por su injusticia, de acuerdo con el dictamen del tiempo" (citamos los fragmentos presocráticos por la edición canónica de Diels-Kranz (DK 19516), con la única salvedad de que, en el caso de Heráclito, prescindimos de la anotación numérica que precede al fragmento e identifica al autor en cuestión).

7 En el caso de Anaximandro, es valioso todavía el estudio de W. Jaeger $1982^{2}$ (1947), pp. 23-24, donde se aborda el pensamiento del milesio desde el punto de vista de la filosofía del derecho y se explica con claridad la diferencia entre nuestro concepto moderno de "ley natural" y el concepto anaximandreo de Justicia cósmica. M. ${ }^{a}$ M. Sassi 2006, pp. 8-18, interpreta el fragmento de Anaximandro a la luz de los conceptos paralelos del lenguaje jurídico

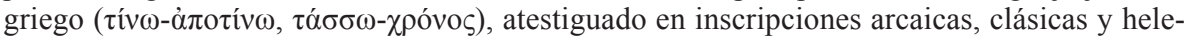
nísticas.

${ }^{8}$ El testimonio es del cronógrafo Apolodoro, recogido por D.L. II 2 (12 A 1). Es posible que esta cronología tan minuciosa formara parte de la $\sigma \varphi \rho \alpha \gamma$ ís del libro de Anaximandro que cayó en manos de Apolodoro; cf. KR 1970 (1966), p. 148. 
(geografía y etnografía) ${ }^{9}$. A su vez, este último aspecto podría haber servido de exégesis escrita al mapa del mundo que, según nuestras fuentes, Anaximandro fue el primero en trazar, siguiendo estrictos criterios geométricos que más tarde inspirarían probablemente el mapa perfeccionado de Hecateo y provocarían la crítica irónica de Heródoto ${ }^{10}$.

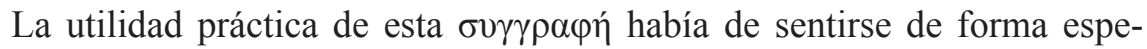
cialmente intensa en los círculos dirigentes de Mileto: el tratado en prosa proporcionaba una codificación de la información geopolítica, de importancia vital para una ciudad cuya subsistencia dependía del comercio marítimo y las relaciones con las colonias que había establecido a lo largo de la franja costera del Mar Negro durante los siglos VII-VI a. C. El viaje de Aristágoras a Esparta ${ }^{11}$ en busca de ayuda para la sublevación jonia, que tuvo lugar unos cincuenta años después de la publicación del libro, ilumina claramente la importancia que la tradición cartográfica jonia, iniciada por Anaximandro y perfeccionada por Hecateo a finales del s. VI a. C., tenía en los planes geopolíticos de Mileto, así como la interacción estrecha entre el diseño del mapa $(\pi i v \alpha \xi)$ y el discurso diplomático al que servía ocasionalmente de ilustración ${ }^{12}$.

La publicación del libro de Anaximandro consolida así, superpuesta a su publicación oral, formas políticamente influyentes de comunicar enseñanzas, a semejanza de la codificación legal arcaica, que prescribe normas y procedimientos en el terreno de la praxis cívico-política. La diferencia está en la extensión del público que utiliza el libro, probablemente más reducido que el público destinatario de las leyes. Por otro lado, la presencia física del libro no es ubicua ni normativa, como la de la ley escrita en la polis arcaica y clásica; pero no por ello es aquél menos custodiado por las élites intelectuales y políticas de Mileto y, quizá, de otras ciudades jonias interesadas en el nuevo estilo de investigación abierto por los milesios $(\pi \varepsilon \rho \grave{~}$

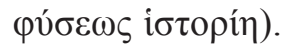

9 Es de suponer que los títulos transmitidos por la $S u d a$, s.v. (12 A 2: ह̌ $\gamma \rho \alpha \psi \varepsilon$ Пврі̀

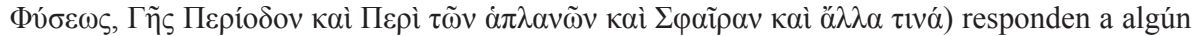
tipo de estructuración interna de la $\kappa \varepsilon \varphi \alpha \lambda \alpha \iota \omega ́ \delta \eta \varsigma ~ \varepsilon ̌ \kappa \theta \varepsilon \sigma ı \varsigma$ que le atribuye Apolodoro. Cf. W. K. C. Guthrie 1984 (1962), p. 80.

${ }^{10}$ Para Hecateo cf. Agathem. I 1 (12 A 6). El testimonio de Heródoto (Hdt. IV 36) es un indicio de una cierta difusión de los mapas anteriores, como justamente señala Chr. Jacob 1989 (1988), pp. 160-161.

${ }^{11}$ Hdt. V 49.

${ }^{12}$ Cf. Chr. Jacob 1989 (1988), pp. 159-165. 
2. Una huella del público del libro la proporciona sin duda la proyección cósmica del lenguaje jurídico de la pólis que Anaximandro utiliza en su universo geométrico. Su isonomía cósmica, con la tierra suspendida en el centro — "no dominada por nadie" ( cualquier punto exterior de la esfera celeste, era una imagen "política" coherente con la búsqueda de un espacio central para el ejercicio del poder, que garantizara el precario equilibrio y la rotación de las magistraturas entre las facciones y heterías de Mileto. Según nuestras fuentes, fueron dos grupos antagónicos e irreconciliables los que lucharon en el estado milesio a lo lar-

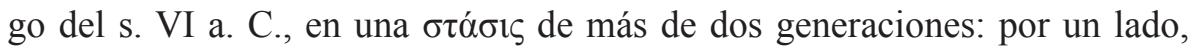
la gran aristocracia terrateniente de los "siempre-navegantes", que, como su nombre indica, en Mileto es asimismo propietaria de naves y, con el control del comercio mediterráneo a gran escala, se había enriquecido considerablemente y presionaba a los pequeños y medianos propietarios de tierras; por

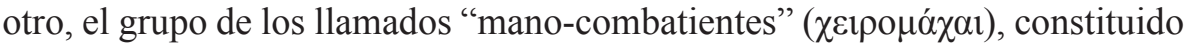
probablemente por campesinos libres que combatían como hoplitas en el ejército y reclamaban, como en otras partes de Grecia, una participación activa en las magistraturas ${ }^{14}$. Próximo quizá a ese grupo, al que cabe identificar con su público inmediato, Anaximandro, si bien no llegó a ver la decadencia de Mileto, contribuyó quizá a atenuar la conflictividad política de su patria cuando, hacia el final de su vida, dirigió una segunda oleada de colonos hacia la ciudad de Apolonia, junto al Mar Negro ${ }^{15}$.

Unos veinte años después de la muerte de Anaximandro, en torno a 525 a. C.,

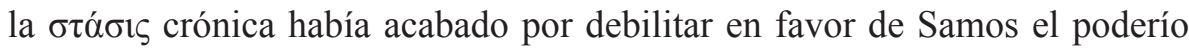
marítimo de Mileto, desgarrada por la violencia del choque entre la aristocracia del mar y el pueblo campesino. Fue finalmente este último grupo el que se alzó con el poder en la metrópoli jonia, gracias a la mediación de una comisión de ciudadanos prominentes de Paros, quienes, quizá ya con el tácito

${ }^{13} 12$ A 11 = Hippol., Haer. I 6.3 .

${ }^{14}$ Cf. Hdt. V 28; Plu., Aet. Gr. 32, 298 C-D. Las interpretaciones del texto de Plutarco son divergentes respecto a la identificación sociopolítica de las heterías enfrentadas en Mileto: cf. S. Mazzarino $1989^{2}$ (1947), pp. 220-225; A. Capizzi 1982, pp. 291-296. Aquí seguimos la hipótesis de L. Braccesi 1982 (1978), pp. 30-33, que interpreta el testimonio de Heródoto como el triunfo de la clase hoplítica sobre la vieja aristocracia, terrateniente-marítima, de Mileto.

${ }^{15}$ Los indicios que sitúan a Anaximandro en la proximidad de ese grupo social están recogidos en A. Capizzi 1982, p. 299. La expedición a Apolonia está contada en Ael., VH III 17 (12 A 3); para las circunstancias concretas de esta empresa, cf. A. Capizzi 1982, pp.310-311. 
apoyo persa, otorgaron el mando a «aquellos que tenían sus campos bien cultivados» (Hdt. V 29). Así se puso fin a la larga crisis política de Mileto, pero esta solución, que contempló el ascenso vertiginoso de Histieo y Aristágoras a la cúspide del poder, en lugar de liberar las fuerzas sociales de la pólis en una dirección isonómica, bloqueó su evolución política y convirtió a esta ciudad en un estado satélite del Imperio persa. Unos decenios después estallaría la sublevación jonia (500-494 a. C.), el último intento — fracasado- de sacudirse ese yugo.

3. De Anaxímenes no sabemos prácticamente nada. El juicio estilístico de Diógenes Laercio, según el cual la prosa jonia de Anaxímenes era "llana y no rebuscada" 16 , sirve quizá de contrapunto, en la literatura doxográfica, a los comentarios que suscitaba el lenguaje "más bien poético" de Anaximandro ${ }^{17}$. Un análisis directo de las pocas palabras que podemos hacer remontar al libro de Anaxímenes muestra que la simplicidad de su dicción jonia no era incompatible con un abundante uso del símil, que servía no sólo a fines didácticos ${ }^{18}$, sino también para establecer correspondencias, a distintas escalas, de lo que consideraba el principio gobernante ( $\dot{\alpha} \rho \chi \eta ́)$ de la

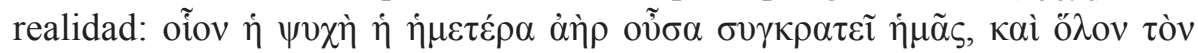

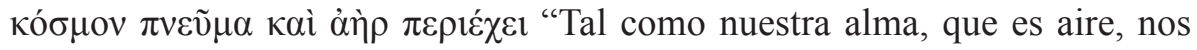
mantiene unidos con su fuerza, así el hálito y el aire abrazan todo el orden del mundo" (13 B 2).

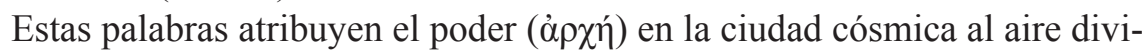
no y vivificador que inunda y cohesiona la totalidad de los seres, tanto dentro de nosotros (nuestra alma) como desde fuera del mundo (como hálito o soplo que circunda el Universo por todas partes). Colli ha descrito con claridad la

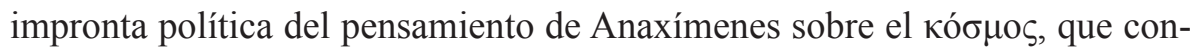
tinúa en este sentido el camino abierto por Anaximandro: «También ahora se establece un orden político, en el que se encuadran individuo y mundo, se decreta una ley y se atribuye la soberanía. Las esferas del mundo y del individuo están perfectamente equilibradas: un dominio único — aire - inunda

${ }^{16}$ D.L. II 3.

${ }^{17}$ Cf. 12 A 9 = Simpl., in Ph. 24. 13-25.

${ }^{18}$ «El sol es plano como una "lámina"» (13 B 2a), «La tierra "cabalga" sobre el aire» (13 A 6), «Los astros están fijos como "clavos" en lo cristalino» (13 A 14). 
las dos esferas, que en cuanto alma gobierna la apariencia del cuerpo, y en cuanto soplo envuelve las apariencias múltiples del mundo» ${ }^{19}$.

\section{Heráclito de Éfeso y la ley de Hermodoro}

La coloración jurídico-legal del discurso de Heráclito inunda toda su doctrina cosmológica $\mathrm{y}$, además, articula la relación de su propio pensamiento con los "maestros de la verdad" que le han precedido en la tarea educativa reservada a los poetas y sabios de la Hélade ${ }^{20}$. En este apartado, nos centraremos en la proyección del discurso de Heráclito sobre la realidad política, jurídica y moral de sus conciudadanos efesios, a quienes el Oscuro exhorta y trata de dirigir con su discurso ( $\lambda$ ó $\gamma \circ \varsigma$ ) en una dirección política y ética determinada.

1. Es, también aquí, la noción de ley (vónos) la que vertebra, tácita o expresamente, las amonestaciones que el Efesio dirige a sus conciudadanos en la vertiente ético-política de su pensamiento. Heráclito está convencido de haber descubierto una Ley divina universal a la que se someten todas las cosas y que tanto el pensamiento como el lenguaje pueden apresar en un discur-

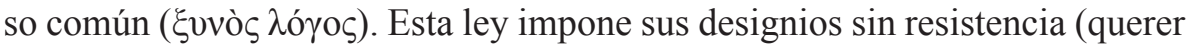
y poder son lo mismo para ella), da sustento a todas las leyes humanas y, aún así, no se agota nunca, sino que siempre prevalece ${ }^{21}$. Se trata del principio divino que gobierna todas las cosas (B 64, B 11) y que, en el discurso de Heráclito, recibe nombres diferentes según el punto de vista desde el que se lo contemple: como principio normativo, es Ley divina, esto es, unidad en el conflicto entre opuestos y garante de la Justicia (B 94) del orden cósmico (= Guerra o Discordia de opuestos: B 53, B 80); como realidad física, es

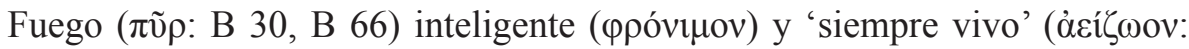

\footnotetext{
${ }^{19}$ G. Colli 1978, p. 34 (la traducción es mía).

${ }^{20}$ Así lo hemos estudiado en nuestra comunicación presentada al I Congreso Internacional de Filosofía Griega (en prensa): cf. supra, n. 5.

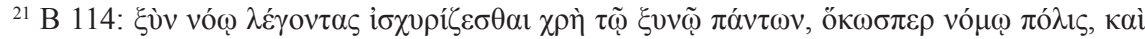

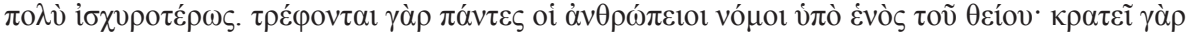

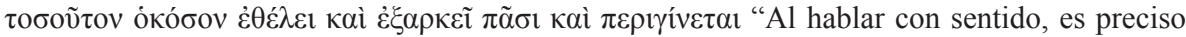
fortalecerse en lo que es común para todos, igual que la ciudad en la ley, y aun con más fuerza: pues todas las leyes humanas se nutren de una sola, la divina; y es que domina tanto cuanto quiere y basta a todas y aun sobra".
} 
B 30), en constante movimiento ("que se enciende según medida y se apaga según medida": B 30); es al mismo tiempo una "inteligencia" ( $\gamma v \omega ́ \mu \eta)$ que "gobierna todo a través de todo" (B 41); es lo único que, con todo derecho, merece recibir el nombre de "sabio" (Ěv nuestro propósito, es especialmente interesante subrayar la estrecha relación de dependencia en que, a los ojos de Heráclito, se encuentran las leyes humanas respecto de la Ley divina formulada en el $\lambda$ ó $\gamma o \varsigma$ del Efesio.

Pues bien, como veremos a continuación, Heráclito no sólo promulgó con solemnidad la Ley divina, sino que, en su ciudad natal, se comprometió activamente con un proyecto político que, entre otras cosas, implicaba la aprobación de una importante reforma legal. La tradición ha asociado dicha legislación a un cierto Hermodoro, y es precisamente éste el único efesio que recibe elogios de parte de Heráclito en los fragmentos. Precisamente, el texto en que aparece mencionado Hermodoro es precioso para determinar desde qué posición política hablaba Heráclito a los de Éfeso y por qué condenó sin remisión a sus conciudadanos cuando el legislador fue desterrado. Si analizamos detenidamente este fragmento, será posible esclarecer el compromiso político de Heráclito en el proyecto de Hermodoro ${ }^{22}$, así como evaluar hasta qué punto es problemática la misteriosa figura que la tradición nos ha legado bajo la leyenda del filósofo misántropo y eremita:

\section{B 121}

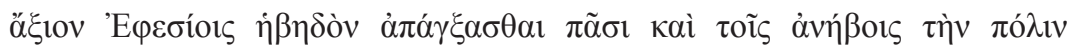

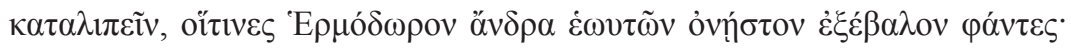
$\dot{\eta} \mu \varepsilon \dot{\varepsilon} \omega \nu \mu \eta \delta \dot{\varepsilon} \varepsilon \tilde{c} \zeta$ ỏv

Lo que merecen los efesios mayores de edad: ahorcarse todos y dejar a los menores el gobierno de la ciudad. Quienesquiera que a Hermodoro, el hombre más valioso de entre ellos, expulsaron diciendo: «ni uno solo de nosotros sea el más valioso; y si no, que lo sea en otra parte y con otra gente».

Este fragmento responde a la condena de destierro promulgada por los efesios contra Hermodoro con una ficticia condena a muerte dictaminada por Heráclito: el suicidio en la horca es la única suerte que merecen los

\footnotetext{
${ }^{22}$ Ese compromiso pudo llevar a Heráclito a exhortar al pueblo "a luchar por la ley como por la muralla” (B 44). Para este fragmento, cf. el excelente análisis de E. Lledó 1994.
} 
ciudadanos adultos de Éfeso por haber impedido que uno solo de entre ellos sobresalga en excelencia y poder en el servicio al Estado. El tono judicial del decreto de destierro, tal como lo recoge Heráclito con evidente ironía, es contrapesado a su vez por una fórmula jurídico-moral de condena ${ }^{23}$. Tal lenguaje sitúa de manera pertinente el trasfondo histórico de este fragmento en las luchas políticas internas de la ciudad de Éfeso en torno al cambio de siglo (s. VI ex. - s. V in. a. C.), en un escenario que, entre otros, Mazzarino y Capizzi - y, entre nosotros, García Quintela - han reconstruido con cierta verosimilitud, pese a que reposa sobre una base documental muy escasa $^{24}$.

Según los testimonios de que disponemos, el servicio de Hermodoro a la polis efesia consistió al parecer en una legislación que, entre otras disposiciones, contenía medidas suntuarias similares a las de otros códigos legales griegos, como los de Solón y Pítaco. Hesiquio, citando a Polemón como fuente, nos informa de una de esas medidas, que, según sus palabras, figuraba por escrito en el código legal de Hermodoro: «que las mujeres libres porten calzado escítico de cuero» ${ }^{25}$. En otras palabras: que usen un tipo de calzado de una modestia inusitada en la aristocracia efesia, acostumbrada

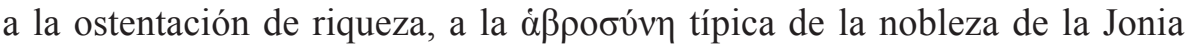
microasiática.

Que los destinatarios principales de estas leyes suntuarias fueran las clases aristocráticas de Éfeso no sólo está implícito en la naturaleza misma

${ }^{23}$ El estilo epigráfico-jurídico del fragmento B 121 es rastreable tanto en el "veredicto" de Heráclito como en la justificación del exilio de Hermodoro, que está construida como si fuese una cita del decreto de expulsión de su amigo: cf. BW 1972, pp. 332-334; A. García

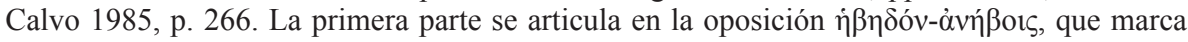
la frontera entre los hombres adultos, en plena posesión de sus derechos cívico-militares, y aquellos que todavía no han pasado la prueba de la efebía. El veredicto de Heráclito, no exento de humor, subvierte el orden de la política hasta caer en el absurdo, el mejor instrumento de su denuncia: la decisión de los efesios merece (äklov) que todos los adultos se ahorquen sin excepción y dejen a los niños el gobierno de la ciudad (véanse otros usos jurídico-políticos del

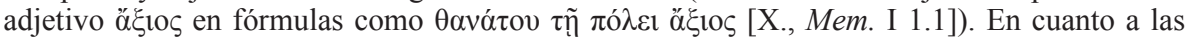
palabras puestas en boca de los efesios, el empleo del imperativo de 3 . $^{\text {a }}$ persona transparenta el juego de Heráclito con el lenguaje legal contemporáneo para denigrar por risible y absurda la decisión de expulsar a Hermodoro.

${ }^{24}$ Cf. S. Mazzarino 1989² (1947), pp. 209-211; A. Capizzi 1982, pp. 314-317; M. V. García Quintela 1992, pp. 44-45, 113-115.

${ }^{25} F H G$ III 147, fr. 96: По

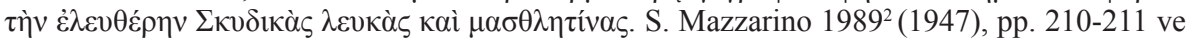
en este texto indicios lingüísticos que nos retrotraerían a fuentes epigráficas. 
de la medida, sino que aparece confirmado explícitamente por otro fragmento $^{26}$, donde, utilizando de nuevo un lenguaje de corte judicial ( $\dot{\varepsilon} \xi \varepsilon \lambda \varepsilon \dot{\gamma} \chi 01 \sigma \theta \varepsilon$

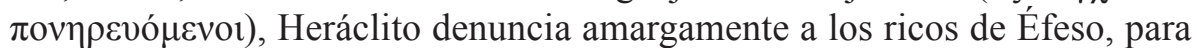
quienes la riqueza es sólo un instrumento de ostentación y abuso de poder ${ }^{27}$. Tales indicios nos pueden dar una pista sobre la naturaleza de la obra legislativa de Hermodoro, que Heráclito apoyaba sin reservas según se desprende de B 121. Una cosa es cierta en medio de tanta incertidumbre: si tenía a la mayor parte de la aristocracia efesia en contra, la legislación de Hermodoro no podía sancionar sin más el privilegio político-económico de las familias nobles.

2. En Éfeso, la encumbrada posición de la nobleza se había perpetuado gracias a un sistema de relaciones matrimoniales y amistosas con el poder continental de la primera mitad del s. VI a. C.: el imperio lidio. Así lo muestran los numerosos ejemplos de patronímicos lidios en familias de la aristocracia efesia ( $\Lambda v \delta i ́ \zeta o v \tau \varepsilon \varsigma)$, sobre todo en la familia de la que provenía Heráclito, la de los "Basílidas", que, como descendientes del rey Androclo, el mítico fundador de la ciudad, retuvieron el poder hasta el primer tercio del s. VI a. C. ${ }^{28}$. Si bien entonces la tiranía arrebató en Éfeso el monopolio de

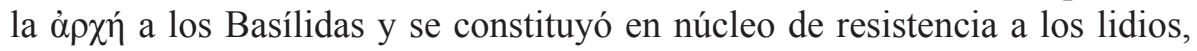
no por ello se detuvo menos la proyección de la ciudad hacia el continente asiático. Este proceso quedó definitivamente sancionado con la conquista de Creso y la ofrenda ritual de la $\pi$ ó $\lambda \varsigma^{29}$, cuando los efesios unieron las mura-

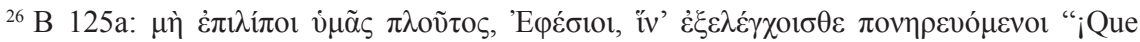
no os falte la riqueza, efesios, para que quedéis convictos de vuestra perversidad!". Aquí seguimos la interpretación de Mazzarino a este fragmento: S. Mazzarino $1989^{2}$ (1947), pp. 209-210.

${ }^{27}$ Véase asimismo la interesante interpretación política realizada por C. Diano-G. Serra 1980, p. 182, al fr. B 96: el desprecio de los cadáveres que Heráclito expresa aquí tan descarnadamente se dirige también contra la magnífica exhibición de lujo de los ritos funerarios de las familias aristocráticas; en sintonía con esta ética de la moderación en la $\pi$ ó $1 \varsigma$, es probable que, lo mismo que Solón en Atenas, Hermodoro, el amigo de Heráclito, haya introducido en Efeso una legislación escrita que limitara el lujo en los funerales.

${ }^{28}$ Una noticia de Antístenes, recogida por Diógenes Laercio (IX 6), nos informa de un hecho crucial en la vida de Heráclito: abdicó de sus prerrogativas reales en favor de su hermano menor. Comparto con García Quintela 1992, pp. 52-62, y Mouraviev 2003, pp. 129-132, que esta decisión permitió a Heráclito participar activamente en la vida política de su ciudad.

${ }^{29}$ En este punto, la conquista de la ciudad por Creso (ca. 554-550 a. C.) marca un antes y un después en la relación entre la tiranía efesia y los lidios: Píndaro, el tirano depuesto por 
llas de la ciudad al templo de Ártemis con un cable, como nos cuenta Heródoto $^{30}$. Una vez subordinada al gigante lidio, la tiranía ahonda aún más la orientalización de Éfeso, y lo hace apoyándose en una aristocracia de la tierra plenamente identificada con los modos de vida asiáticos, extraordinariamente rica y, como tal, aferrada a un estilo de vida ostentoso: el ideal aristocrático de la $\dot{\alpha} \beta \rho o \sigma u ́ v \eta^{31}$.

Es ésta, probablemente, la nobleza que ve amenazada su posición dominante por la propuesta legislativa de Hermodoro, con medidas que, por desgracia, se nos escapan en sus pormenores (salvo en el caso aludido), pero que apuntan a una contención espiritual y material del estilo de vida aris-

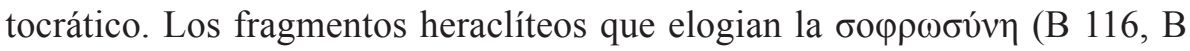
112, B 43, quizá B 110) están en consonancia con esta postura ético-política del círculo de Heráclito-Hermodoro. Además, la legislación suntuaria no se agotaba en medidas de contención material, sino que ponía en cuestión el estilo de vida de una aristocracia ávida de extender sus riquezas a costa del pueblo ${ }^{32}$.

En este sentido, la fórmula heraclítea del decreto de expulsión de Hermodoro ("que no sobresalga..."), aun expresando una inquietud "democrática", no está reñida con la interpretación aquí ofrecida del fr. B 121. En efecto, el temor ante una acumulación excesiva de poder en las manos de un solo ciudadano - en este caso, de un legislador y consejero investido al parecer de prerrogativas especiales (cf. frs. B 33 y B 49) — arraigaba, como es sabi-

Creso y enviado al exilio, había liderado la resistencia de los efesios contra el imperio lidio, como ya probablemente hiciera su antecesor, Pitágoras, tras derrocar a los Basílidas del poder (en un proceso paralelo, pero quizá algo posterior, al iniciado en Mileto por Trasibulo en el primer decenio del s. VI a. C.). Después de la conquista de Creso, los tiranos sucesivos (se tienen noticias de Pasicles y Melas bajo el reinado de Creso) gobiernan bajo el paraguas lidio, pero con un cierto grado de autonomía, como demuestra el paréntesis legislativo del ateniense Aristarco (Suda, s.v.): cf. S. Mazzarino 1989² (1947), pp. 190-193; A. Capizzi 1982, pp. 312313; M. V. García Quintela 1992, pp. 34-36.

${ }^{30}$ Hdt. I 26. La progresiva orientalización de Éfeso, claramente visible en la relación entre Creso y el templo de Ártemis, y que culmina en la $\kappa \alpha \tau \alpha ́ \beta \alpha \sigma ı \varsigma$ de la ciudad desde su antiguo emplazamiento, en la colina del Coreso, hasta el espacio en torno al Artemisio (documentada por Str. XIV 1. 21, pero hay dudas sobre su cronología exacta), ha sido muy bien analizada por S. Mazzarino 1989² (1947), pp. 197-199; cf. también M. V. García Quintela 1992, pp. 36-37.

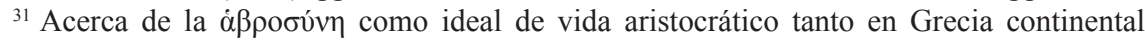
como en las islas y Asia Menor, cf. S. Mazzarino 1989² (1947), pp. 206-209, 211-214.

${ }^{32}$ Esta tesis de Mazzarino ha sido desarrollada posteriormente por R. Schottlaender 1965, pp. 25-26, y retomada por A. Capizzi 1979, pp. 47-50. 
do, no sólo en el pueblo (piénsese en la situación de la Atenas isonómica de Clístenes, con la institución del ostracismo), sino también entre las familias aristocráticas, que veían cómo sus privilegios eran cuestionados por las aspiraciones de nuevos grupos emergentes, canalizadas a través de la atribución de poderes extraordinarios a una sola persona: así lo muestra ejemplarmente, con la distancia de casi un siglo, el odio obsesivo de Alceo hacia Pítaco en Mitilene o la desconfianza de la aristocracia ateniense hacia Solón ${ }^{33}$. Es bastante probable que, como el fragmento comentado deja traslucir, la expulsión de Hermodoro se produjera por decisión popular, en forma quizá semejante al procedimiento del ostracismo ateniense ${ }^{34}$, pero a la iniciativa, como en Atenas, no serían indiferentes los beneficiarios directos de tal expulsión, entre los cuales se encontrarían ciertas familias nobles rivales, ocasionalmente aliadas con el pueblo para desterrar al hombre fuerte de Éfeso y conjurar el fantasma de la tiranía.

3. De todos modos, las circunstancias concretas que impulsaron el proyecto legislativo de Hermodoro en Éfeso se nos escapan por completo. Las opiniones son también aquí divergentes. El compromiso antiaristocrático de Heráclito, tal como lo hemos analizado arriba, supone un serio golpe a la explicación tradicional, según la cual esta empresa de codificación escrita no fue sino la resistencia inútil de una aristocracia inmovilista a plegarse a los vientos de la historia, que en Jonia, a finales del s. VI a. C., soplaban con fuerza a favor de la instauración de regímenes isonómicos y de la independencia política de Persia, objetivo de la revuelta jónica (500-494 a. C.). Desde este paradigma interpretativo, Hermodoro podría haber sido desterrado por su amistad con los persas, partidarios de los nobles opulentos de Éfeso ${ }^{35}$. E1

\footnotetext{
${ }^{33}$ El conservadurismo de la aristocracia "lidizante" de Éfeso, que convive con la pobreza extrema de la mayoría de la población (de la que varios fragmentos de Hiponacte son testigos directos y vívidos: cf. Hippon., frs. 26, 32, 33, 34 Adrados), permite equiparar la situación sociopolítica de la Éfeso de Heráclito con la de la Atenas de Solón, de la que le separa casi un siglo de historia: «Alla Efeso del 500 a. C., alla Efeso di Eraclito, si ponevano i problemi medesimi che travagliavano, p. es., Atene nei primi del $6^{\circ}$ secolo» (S. Mazzarino $1989^{2}$ [1947],

${ }^{34}$ Así lo sugiere por lo demás el modo en que Cicerón (Tusc. V 36) empareja estas dos ciudades cuando, refiriéndose a desterrados ilustres expulsados por la envidia del pueblo, equipara los ejemplos de Hermodoro y Aristides "el Justo". Cf. A. Capizzi 1982, p. 317; S. Mouraviev, 2003, pp. 139-140.

${ }^{35}$ Cf. M. Marcovich 1978, p. 372 y la bibliografía allí recogida.
} p. 210). 
problema de esta reconstrucción es que, desde una ideología aristocrática cerrada, resulta difícil, como hemos señalado arriba, justificar las medidas suntuarias de Hermodoro: aunque quisiéramos ver en ellas una serie de concesiones inevitables de la propia nobleza para que las cosas siguieran más o menos como estaban, resultaría casi increíble contemplar cómo la aristocracia de Éfeso, a propuesta de uno de los suyos, se imponía a sí misma, en bloque, limitaciones morales y económicas que atentaban directamente contra su estilo de vida.

No es fácil, sin embargo, determinar con exactitud ni el sentido del proyecto político de Hermodoro ni, en función de éste, la localización cronológica de su tarea legisladora en Éfeso. A mi juicio, lo más razonable es, como sugiere la mayoría de los investigadores, situar esa reforma legal todavía bajo dominio persa, en los albores de la revolución jónica ${ }^{36}$. En ese caso, es oportuno preguntarse si esto significaba o no un desafío contra el Gran Rey, que, como sabemos por el ejemplo de Mileto, sostenía tiranías afectas en las ciudades jonias. En mi opinión, un proyecto legislativo liderado por un personaje de prestigio, como Hermodoro, y precedido por la renuncia de un tirano —un tal Melancomas, si es que damos crédito a la noticia de que Heráclito lo persuadió para que dejara el poder ${ }^{37}$-, no tendría por qué haber causado alarma en

${ }^{36}$ Estos acontecimientos podrían haber coincidido aproximadamente con la madurez

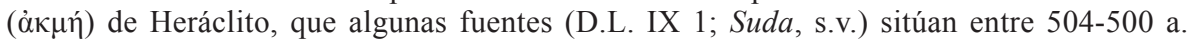
C. (69 $9^{\text {a }}$ Olimpíada). Nuestra reconstrucción asume, pues, las fechas que la mayoría de los críticos fijan para el nacimiento y la muerte de Heráclito: ca. 540-480 a. C. Pero debe advertirse que esta cronología reposa sobre la aceptación de dos noticias cruzadas: la edad de la muerte del filósofo (60 años: cf. D.L. VIII 52, IX 3, en una noticia que remonta hasta

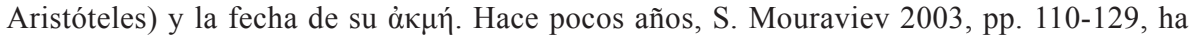
sometido a crítica esta datación tradicional y ha propuesto en su lugar una cronología más

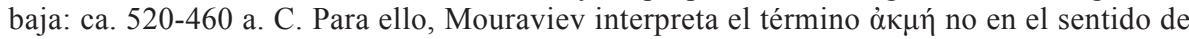
madurez física e intelectual (en torno a los 40 años), sino como el momento culminante de la biografía de un personaje. En el caso de Heráclito, ese momento (504-500 a. C.) sería el de su renuncia al título de rey, que le correspondía heredar como primogénito de la familia de los Basílidas (cf. supra, n. 28). Tal renuncia se produjo, según el investigador ruso, cuando el joven Heráclito cumplió la edad de la efebía (entre 18 y 20 años) y asumió las obligaciones político-militares de la edad adulta. La propuesta cronológica de Mouraviev retrasa también la localización de los principales acontecimientos de la vida política de Heráclito: cf. infra, 2.5. Aun siendo conscientes de lo hipotético de cualquier reconstrucción con tan pocos datos seguros, nosotros creemos (y así queremos mostrarlo aquí) que es posible encontrar verosimilitud histórica a esos acontecimientos, aun manteniéndonos en la cronología tradicional.

${ }^{37}$ Clem. Al., Strom. I 65. 
Persia, sino que podría haberse realizado con el nihil obstat del sátrapa ${ }^{38}$. El imperio aqueménida fue en general bastante flexible y tolerante en el respeto de las tradiciones helénicas de gobierno en las ciudades jonias: sus prioridades en este terreno pasaban por asegurarse la sumisión de cada estado, mediante el cobro del tributo y la imposición de guarniciones, pero dentro de un cierto margen de autonomía política. Por eso, si en la mayoría de las ciudades la tiranía fue el medio de subordinar Jonia al imperio persa, en otras comunidades no era imposible que se optase por otras soluciones. Quizá fuera ése el caso de la hipotética exaltación de Hermodoro a la condición de esimneta en Éfeso, ostentando una "tiranía electa" que, con el acuerdo de casi todas las facciones y el beneplácito de los propios persas, legislara en su ciudad natal una constitución que evitase fracturas políticas y sociales irreparables.

Por otro lado, sabemos por Heródoto que los efesios no participaron en la rebelión jonia desde posiciones de vanguardia y se retiraron de ella en cuanto las cosas se torcieron. Aunque la toma e incendio de Sardes (498 a. C.), el principal golpe de mano de los jonios contra los persas, tomó como base de operaciones la ciudad de Éfeso ${ }^{39}$, a partir de ese momento la implicación de la polis de Heráclito en la revuelta contra los persas decayó, hasta el punto de que los efesios ya no estaban entre los jonios que lucharon en la batalla naval de $\operatorname{Lade}^{40}$ (495 a. C.) e incluso mataron a algunos combatientes de la isla de Quíos, que regresaban a su patria tras la derrota a través del continente, cruzando territorio efesio ${ }^{41}$. Ello quiere decir que quizá en Éfeso la situación de semidependencia respecto a los persas no se consideraba tan gravosa como en otros lugares, pues éstos les dejaban un amplio margen de autonomía para gobernar los asuntos de la ciudad.

\footnotetext{
${ }^{38}$ Si la legislación de Hermodoro y la caída de Melancomas tuvieron lugar antes de la rebelión jonia contra los persas, no podrían haber constituido un desafío al Gran Rey, porque, de ser así, Éfeso se habría anticipado a todas las ciudades jonias en su reivindicación de autonomía (algo que no está corroborado en absoluto por nuestras fuentes). Pero si fue un movimiento antipersa, sólo cabe identificarlo como la rebelión jonia en Éfeso, lo que nos lleva a la inverosímil figura de un Heráclito democrático (cf. infra, II.4).

${ }^{39}$ Hdt. V 99-102. S. Mouraviev 2003, pp. 132-134, sospecha que la participación de Éfeso en las operaciones de la campaña contra Sardes pudo haberse producido bajo coacción, lo que permitiría explicar que los persas no tomaran represalias contra la ciudad de Heráclito. En este contexto podría situarse la historia narrada por Temistio (de uirt., p. 40 s.), según la cual Heráclito convenció a los persas para que abandonaran el asedio de Éfeso. Sea lo que fuere, lo cierto es que, a partir de esa campaña, Éfeso no se implicó más en la revuelta jonia.

${ }^{40}$ Hdt. VI 8.

${ }^{41}$ Hdt. VI 15-16.
} 
Por eso, no nos parece inverosímil que la obra legislativa de Hermodoro y su consiguiente enaltecimiento como hombre fuerte de Éfeso se realizasen antes de la rebelión jonia y bajo tutela persa. Nuestra reconstrucción del trasfondo político de la legislación de Hermodoro, ampliamente conjetural, supondría que los persas apostaran en Éfeso, como lo hicieron ya en Mileto, por ciertas facciones de la vieja aristocracia aliadas con el campesinado medio (clase hoplítica). Estos grupos estarían decididos a contener los abusos de las ricas familias de Éfeso para imponer un orden político estable y neutralizar potenciales revoluciones "democráticas". Así, los persas habrían transigido con una $v 0 \mu 0 \theta \varepsilon \sigma i ́ \alpha$ en la polis jonia más vinculada a su satrapía de Lidia, y le habrían garantizado un cierto grado de autonomía local, siempre que no amenazara la relación de poderes entre ambos estados. De una

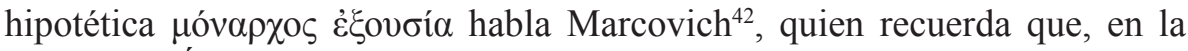
historia de Éfeso, ya se habían realizado reformas legislativas en la época de dominio lidio, por ejemplo la atribuida a Aristarco de Atenas hacia la mitad del s. VI a. C.

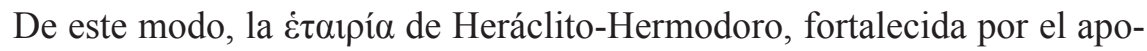
yo persa, entrañaba, a los ojos de las facciones contrarias de la nobleza y

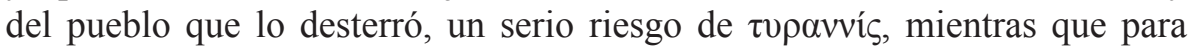
Heráclito se trataba sobre todo de apuntalar el imperio de la ley ${ }^{43}$. A su vez, no podemos descartar tendencias demagógicas en los nobles enemigos de Heráclito, que aprovecharían la ocasión de la rebelión jónica para ajustar cuentas con el líder de la facción imperante, desterrando a Hermodoro con el voto de la mayoría del pueblo. Si este proceso culminó con la hipotética sustitución de Hermodoro, el hombre fuerte de Éfeso, por un régimen isonómico de cuño democrático, como relata Heródoto que sucedió en casi todas las ciudades jonias sublevadas contra los persas ${ }^{44}$, los nobles de Éfeso enemigos de la facción de Hermodoro y Heráclito no habrían hecho nada por impedirlo, pese a que esta evolución política era mucho más inquietante para sus intereses. Pero es probable que la propagación vertiginosa de la revolución jonia no aconsejara en esos momentos de fervor patriótico cerrarse en posiciones conservadoras, y sólo cuando se enfriaron los ánimos y vinieron las

\footnotetext{
${ }^{42}$ M. Marcovich 1978, pp. 367-368.

${ }^{43}$ El fragmento B 44 es terminante en este sentido y habla muy bien de la importancia de la ley, tal como la concebía Heráclito, como factor cohesionador de la polis y mediación de intereses opuestos. Cf. R. Caballero 2005a, pp. 202-204.

${ }^{44}$ Hdt. V 38.
} 
derrotas, esos aristócratas aprovecharían la situación para apartar a Éfeso de la rebelión contra los persas.

En esta reconstrucción, pues, tendríamos a un Heráclito cercano a los persas, como lo suponía la imagen de la historiografía tradicional, pero no por ello necesariamente atrincherado en posiciones monolíticas de la aristocracia. En efecto, su talante antidemocrático, para mí indudable (en el sentido del poder nivelador de este sistema de gobierno, contra el que se pronuncia el fr. B 121), no estaría reñido con una posición política abierta al diálogo con nuevos grupos emergentes que reclamaban una cuota de participación acorde con sus deberes defensivos. Otra vez, las figuras de Solón de Atenas, Pítaco de Mitilene o Biante de Priene nos proporcionan ejemplos aproximados de lo que pudo ser la vocación política de Heráclito ${ }^{45}$.

4. Así pues, impugnar la imagen de un Heráclito aristocrático a ultranza no significa necesariamente abrazar la contraimagen de un Heráclito democrático: en efecto, si aquella interpretación nos conduce a un callejón sin salida, tampoco es muy verosímil el intento opuesto de interpretar la legislación de Hermodoro en un sentido "democrático" y antipersa: como un movimiento de libertad acelerado por el fragor del derrocamiento de las tiranías filopersas que acompañó a la rebelión de los jonios contra el Gran Rey. De acuerdo con esta hipótesis, la legislación de Hermodoro fue consecuencia del estallido de la rebelión jonia contra los persas, que, como hemos visto, desencadenó la sustitución de esos regímenes tiránicos por gobiernos isonómicos en casi todas las ciudades. En este caso, el destierro de Hermodoro se habría producido, pocos años más tarde, por el enfriamiento de la rebelión en Éfeso, que, como hemos visto arriba, no tardó mucho en perder fuelle. Ésta es la línea interpretativa iniciada por Mazzarino ${ }^{46}$ que, si bien no formula expresamente tal hipótesis, sí insiste en el carácter medizante de la tiranía jónica en esta época, con el fin de distanciar de los persas a Heráclito, a quien considera enemigo de la tiranía. Es Capizzi ${ }^{47}$ quien convierte a Heráclito y Hermodoro en los líderes de la rebelión antipersa en Éfeso, sacando las últimas consecuencias de la tesis de Mazzarino. En mi opinión, esta hipótesis, aunque sugerente, no sólo no está avalada por el relato herodoteo de la rebelión jonia, sino que no

${ }^{45}$ Cf. Ch. H. Kahn 1979, pp. 2-3.

${ }^{46}$ S. Mazzarino $1989^{2}$ (1947), p. 209.

${ }^{47}$ A. Capizzi 1979, pp. 47-50; 1982, pp. 314-317. 
encaja con el fin político democratizante al que apuntaba tal proceso, no por azar auxiliado por la Atenas de Clístenes, al menos en los dos primeros años de la sublevación ${ }^{48}$.

5. Una última posibilidad es situar la actividad legislativa de Hermodoro en los años posteriores al aplastamiento de la rebelión, esto es, entre 492-482 a. C. Ésta es la línea seguida por Mouraviev, que traza un cuadro histórico ciertamente verosímil, aunque no menos expuesto a la incertidumbre que el que nosotros defendemos. Del tono antitiránico de B 121, Mouraviev saca la conclusión de que fue una asamblea democrática la que, en un procedimiento quizá similar al del ostracismo ateniense, desterró a Hermodoro de Éfeso. Como la democracia no fue restaurada en Éfeso hasta 492 por Mardonio ${ }^{49}$, no sería posible situar antes la expulsión del amigo de Heráclito. En efecto, Mouraviev considera que en 499, al estallar la revuelta jónica, se produjo una "restauración ficticia" de la democracia en las ciudades jonias ${ }^{50}$. Pero éste es, precisamente, el dictamen de Heródoto, tan poco piadoso con Aristágoras: el derrocamiento de la tiranía en su caso fue ficticio y la instauración de la isonomía una maniobra para atraer al pueblo de Mileto a la causa de la revuelta $^{51}$. De los demás tiranos de las ciudades, Aristágoras dejó que cada cual eligiera el destino que le esperaría a cada uno; en cualquier caso, el propio Heródoto reconoce que, «en la mayor parte de las ciudades, se limitaron a desterrar al que había sido su tirano» ${ }^{52}$. En el caso de Éfeso, Mouraviev propone una excepción a esta regla: Melancomas habría permanecido al mando, desempeñando una política oportunista según soplara el rumbo de los acontecimientos, sin desafiar a los jonios al principio para no comprometer a su ciudad y sin dejar de acercarse a los persas a medida que la causa jonia se debilitara. Sólo cuando fueron restablecidas las democracias en Jonia por decisión de Mardonio (492 a. C.), la posición de Melancomas se habría debilitado y el propio Heráclito lo habría convencido para dejar el poder y así dar paso al régimen democrático, instituido por los persas con el sostén de Heráclito y Hermodoro ${ }^{53}$.

\footnotetext{
${ }^{48}$ Cf. Hdt. V 103.1.

${ }^{49}$ Cf. Hdt. VI 43.3.

${ }^{50}$ S. Mouraviev 2003, p. 139.

${ }^{51}$ Hdt. V 37.2.

${ }^{52}$ Hdt. V 38.1 (la traducción es de C. Schrader).

${ }^{53}$ S. Mouraviev 2003, p. 137.
} 
En mi opinión, esta reconstrucción de los hechos choca con algunas dificultades. Primero, si la expulsión de Hermodoro fue decidida por el pueblo en asamblea, bien podría haberse producido en 499 a. C., si es que Éfeso, como la mayoría de las ciudades, instituyó también una democracia isonómica y depuso al que era su hombre fuerte, precisamente Hermodoro. Amén de B 121, los fragmentos B 33 y B 49 atestiguan la simpatía de Heráclito por el poder de un solo ciudadano, si estaba avalado por la excelencia. Si esos fragmentos se hacen eco de la poderosa influencia que tuvo Hermodoro en los asuntos de Éfeso, hasta el punto de ser visto por Heráclito como una especie de árbitro investido de poderes especiales, esto casa mal con el juego democrático que instituyó Mardonio en las ciudades jonias tras la rebelión, cuyo objetivo no declarado era que se enfrentaran distintas facciones con parejas fuerzas y nadie acumulase poderes excepcionales. En segundo lugar, nada hay en los fragmentos de Heráclito que permita sospechar una mínima simpatía de éste hacia la democracia. Si Hermodoro y Heráclito colaboraron con los persas, resulta poco creíble que lo hicieran en la instauración de una democracia. Incluso imaginando a un Hermodoro democrático que legisla para los efesios a iniciativa de los persas, e instaura una democracia vigilada desde Sardes, resultaría muy difícil de justificar el destierro del amigo de Heráclito por el pueblo de Éfeso a espaldas del imperio persa, cuando, como sostiene el propio Mouraviev, fueron los propios persas quienes se apoyaron en Heráclito y Hermodoro para instituir la democracia en Éfeso ${ }^{54}$.

Otra cosa es que el exilio de Hermodoro hubiera tenido lugar después de 478 a. C. y de la constitución de la liga ático-délica, que puso en la órbita ateniense a toda Jonia: entonces la retirada persa del Egeo ante el empuje de las naves atenienses podría haber arrastrado a Hermodoro, que se habría quedado sin sus valedores asiáticos. Pero este escenario sigue tropezando, a mi juicio, con el obstáculo de un Heráclito democrático que defiende ante el pueblo al líder de su facción. En lugar de eso, me parece más verosímil situar en una cronología baja (esto es, después de la revuelta de los jonios) no la legislación de Hermodoro, sino la negativa de Heráclito a legislar para los efesios cuando éstos se lo pidieron ${ }^{55}$, una decisión fundada en que «la ciudad

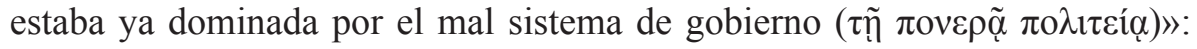
si esta historia tiene algo de verdad, tal expresión aludiría quizá a las demo-

\footnotetext{
${ }^{54}$ S. Mouraviev 2003, p. 140.
}

${ }^{55}$ Cf. D.L. IX 2. 
cracias instauradas por los persas en Jonia tras la rebelión o, menos probablemente, a las alentadas por los atenienses en el Egeo cuando instituyeron la liga ático-délica.

\section{La consagración del libro de Heráclito en el Artemisio}

En la sección anterior, hemos comprobado cómo la noción de Ley en Heráclito, así como su activo apoyo a la legislación de Hermodoro en Éfeso, ayudan a entender el lógos de nuestro filósofo como una mediación privilegiada entre la Ley divina y las leyes humanas. Ello puede, a su vez, arrojar luz sobre el significado simbólico que está detrás de la consagración del libro en el templo de Ártemis ${ }^{56}$, entendido como un acto de publicación consciente, que, en el caso de un tratado en prosa, reviste tanta importancia, o más si cabe, que la publicación de las leyes de la ciudad. En esta segunda parte, queremos explorar con mayor detenimiento si existe en los propios fragmentos de Heráclito huellas ciertas de las motivaciones últimas que lo llevaron a la consagración del libro en el Artemisio. Se trata, pues, de rastrear, en la medida de lo posible, el punto de vista del propio Heráclito sobre lo que entrañaba la publicación del libro, tanto oral como escrita, en la Éfeso de fines del siglo VI a. C., es decir, en un medio cultural que no nos ha dejado ningún testimonio de la existencia de usuarios-lectores de $\operatorname{libros}^{57}$.

1. El significado que podemos asignar a la consagración del libro de Heráclito en el templo de Ártemis efesia no es unívoco, sino que admite interpretaciones desde distintos puntos de vista ${ }^{58}$. En principio, tenemos su-

\footnotetext{
${ }^{56}$ No es mi intención detenerme aquí soble la compleja problemática filológica que plantea el libro de Heráclito. Para ello, remitimos al rico estudio de S. Mouraviev 2003, pp. 187-208.

${ }^{57}$ Sobre las condiciones culturales de la Éfeso "preliteraria" de la época de Heráclito y la inexistencia de un público abstracto lector de libros, ha trazado un exhaustivo cuadro el estudio de K. Robb 1983b, pp. 155-159.

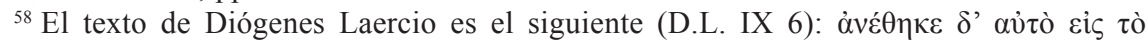

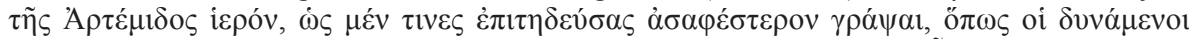

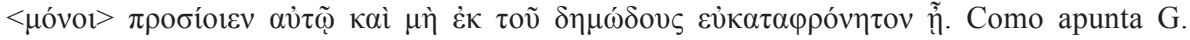
F. Nieddu 1984, pp. 222-223, ni este ni otros testimonios dan pie para sospechar que la consagración del libro tuviera lugar por fuerza antes de las lecturas públicas para así mantenerlo a salvo del desprecio del pueblo. Es lícito suponer que el libro iría creciendo por acumulación a medida que Heráclito lo diera a conocer en sucesivas lecturas y que, cuando
} 
ficientes noticias de textos literarios consagrados en diversos santuarios de Grecia como para hacer verosímil la versión de Diógenes Laercio en el caso particular de Heráclito. Pero quizá no sea indiferente señalar que tales ejemplos, no por azar, comparten la circunstancia de que o eran obras poéticas o fueron inscritas sobre materiales duros (o ambas a la vez): a) el Himno a Apolo de Homero, inscrito por los delios en el registro y depositado en el templo de Ártemis, en conmemoración por la ciudadanía panjonia otorgada a aquél (Certamen 320-321); b) los Trabajos y Días de Hesíodo en láminas de plomo, en el monte Helicón (Paus. IX 31.5); c) la Olímpica VII de Píndaro en tablillas de oro, en el templo de Atenea en Lindos, Rodas (Sch. Pi., O. 7); d) una tablilla de bronce ofrendada por el astrónomo Enópides de Quíos en Olimpia y que contenía un diseño astronómico (Ael., VH X 7); e) un libro de oro ofrendado antiguamente por Aristómaca de Eritras al tesoro de los sicionios en ocasión de sus victorias como rapsoda en los Juegos Ístmicos, según el testimonio del geógrafo Polemón (Plu., Mor. 675 B); e) obras poéticas de Crántor lacradas y depositadas en el templo de Atenea en su patria de Soli, Cilicia (D. L. IV 25).

En todos estos casos, parece tratarse de ofrendas rituales que apuntan a la dedicación votiva de textos poéticos valiosos para una persona o una comunidad y que son ofrecidos a los dioses por motivos religiosos y conmemorativos, no muy divergentes de los que inspiraban las ofrendas de tesoros y demás objetos de valor en los templos. Así pues, el caso de Heráclito, si bien respaldado por algunos de estos ejemplos (pues le sirven de precedentes), es un unicum, en cuanto que se trata de un libro en prosa, en el formato tradicional del rollo de papiro, y un libro que rompe con la tradición poética anterior y se reivindica como la expresión de una Ley eterna y universal, aún más válida y coactiva que todas las leyes humanas. En este sentido, pienso que las motivaciones de la consagración, aun coincidiendo en parte con las que hay detrás de las ofrendas arriba señaladas, van más allá de ellas: al valor conmemorativo y simbólico de la dedicación, que entronca este libro con los textos legales (en concreto, con el de Hermodoro), se unen otros significados intrínsecos al $\lambda o ́ \gamma o \varsigma$ heraclíteo, de los que hablaremos más adelante (3.3.2).

lo consideró terminado, lo ofrendara al templo de Ártemis. Esto lo hizo, como mínimo, no antes del destierro de Hermodoro (B 121), sea cual sea la localización cronológica de este suceso (cf. supra, 2.3-5). 
2. Hasta ahora, las interpretaciones que se han dado al gesto de la ofrenda ritual de Heráclito, tan singular en un formato librario como el rollo de papiro, se han movido entre dos posiciones antitéticas. En un extremo, Schmidt veía en él una «disposición testamentaria» ${ }^{59}$ y Taciano lo interpretaba como un medio de transmisión esotérica, sólo para iniciados, de su pensamiento ${ }^{60}$. En contra de estas hipótesis, intentaré mostrar más adelante (cf. infra, 3.3.1) que Heráclito, al ofrecer su libro a Ártemis, no quería hurtarlo a sus conciudadanos, sino situarlo simbólicamente en el centro de la vida política de Éfeso, como se hacía con las leyes en los espacios públicos de la ciudad (los templos o el ágora).

En el otro extremo, estudiosos más recientes han defendido que la ofrenda del libro constituía un acto consciente y deliberado de publicación literaria en el sentido en que lo entendemos nosotros, esto es, una estrategia de difusión y propaganda destinada a obtener un público lector ${ }^{61}$. Según esta hipótesis, Heráclito se habría dirigido a sus potenciales lectores con la mediación "editorial" del templo. A mí esta manera de ver las cosas me parece excesivamente anacrónica y concentra el foco sobre un concepto - el de la relación entre el autor y sus lectores anónimos- que resulta muy problemático de establecer en la Grecia Arcaica ${ }^{62}$. Es probable que la lectura oral-aural del libro de Heráclito fuera facilitada por su depósito en el Artemisio, si es que pudieron acceder a ese ejemplar aquellos de sus visitantes que estuvieran interesados en su lectura/audición o incluso en su copia para ser transportada fuera de Éfeso ${ }^{63}$. Pero ese hecho, que tiene que ver con la transmisión textual de Heráclito en la Antigüedad ${ }^{64}$, no quiere decir necesariamente que la difusión

${ }^{59}$ GGL 1929, p. 747 n. 1.

60 Tat., Orat. III 1. Esta tesis está inspirada por el testimonio de Diógenes Laercio y ha sido seguida en nuestra época por Teichmüller y otros: cf. bibliografía apud E. Zeller-R. Mondolfo 1961, p. 12, n. 4. 64-65.

${ }^{61}$ G. F. Nieddu 1984, pp. 222-223; M. Conche 1986, p. 8; M. V. García Quintela 1992, pp.

${ }^{62}$ Cf. K. Robb 1983b, pp. 155-159.

${ }^{63}$ En la versión de D. L. (II 22), la tradición biográfica antigua cuenta cómo Eurípides se hizo con un ejemplar del libro de Heráclito y se lo dio a leer a Sócrates, quien, tras reconocer la nobleza de lo escrito en él, confesó necesitar la ayuda de un nadador de Delos para no ahogarse en las profundidades de su pensamiento.

${ }^{64}$ Sin una lectura oral-aural directa del libro, independiente ya de su autor, es difícil explicar las huellas estilísticas y temáticas de Heráclito que pueden rastrearse en algunas obras compuestas a lo largo del siglo V a. C.: algunos pasajes de comedias perdidas de Epicarmo (si es que son suyos los fragmentos de contenido filosófico que les atribuyen las fuentes antiguas), 
y la propaganda fueran los fines primordiales de la publicación originaria del libro en su ciudad natal. Por otro lado, si la ofrenda del libro en el templo equivaliera, salvando las distancias, a lo que hoy entendemos por la edición de un texto literario, se trataría de una edición de ejemplar único, que sólo sería reproducido por petición expresa de unos pocos interesados en tener una copia en su poder.

A mi juicio, es posible que ocurriera justo lo contrario: que Heráclito confiara el libro al templo de Ártemis sólo después de haber advertido que los modos orales-aurales de publicación, entonces corrientes, exponían su texto a una inestabilidad inquietante, y que el peligro aumentaba a medida que la fama del libro, reproducido quizá ocasionalmente por medios privados, se extendía. Si la popularidad del libro pudo preceder a su consagración votiva, aquélla no fue su objetivo: más que un instrumento de difusión editorial, el libro de Heráclito depositado en el Artemisio parece síntoma de una reacción cautelosa y conservadora dirigida a preservar la integridad del $\lambda$ ó ${ }^{\circ} \varsigma$ que el Efesio había ido esculpiendo progresivamente con su voz y su cálamo. Más abajo (3.3.2) desarrollaremos esta cuestión con mayor detenimiento.

3.1. En primer lugar, nos centraremos en el significado conmemorativo de la ofrenda del libro. En algunos fragmentos, ciertos indicios relevantes nos hacen sospechar que Heráclito era consciente de que, con la dedicación del texto escrito, estaba cumpliendo un acto de publicación de naturaleza política y fuerza simbólica, si bien un acto en principio circunscrito a la comunidad efesia que constituía su público inmediato. Para ver esto con mayor claridad, analizaremos en primer lugar aquel fragmento en que Heráclito ataca con virulencia no exenta de humor la vocación de secreto de la comunidad pitagórica.

\section{B 129}

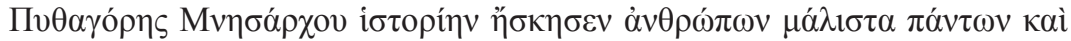

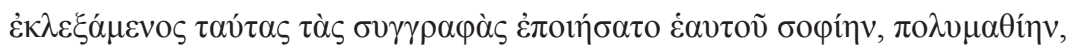

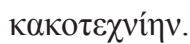

\footnotetext{
el poema de Parménides, el tratado hipocrático Sobre la dieta y algunas máximas de Demócrito. De estos autores, los ecos heraclíteos de Epicarmo (fr. 23 B 1-2 DK = fr. 170 Kaibel) y Parménides (sobre todo, fr. B 6 DK), de ser ciertos, nos permitirían situar en una fecha en torno al 475-470 a. C. el impacto más temprano del lenguaje y el pensamiento de Heráclito en autores casi contemporáneos, y ello en un área geográfica (Magna Grecia) muy distante de su ámbito de producción original.
} 
Pitágoras, hijo de Mnesarco, cultivó la investigación el que más entre todos los hombres y, tras espigar en esos tratados en prosa, se fabricó una sabiduría de su exclusiva propiedad: muchos saberes, malas artes.

A juicio de Kahn, este fragmento presupone la existencia, en la Jonia del siglo VI a. C., de tratados en prosa ( $\sigma 0 \gamma \gamma \rho \alpha \varphi \alpha i)$ de carácter científico, en unas condiciones histórico-culturales bien definidas: en primer lugar, tales escritos habrían sido ya publicados en una medida suficiente como para que Pitágoras hubiera podido, extractando material a partir de ellos, modelar la pseudosabiduría propia que le ha hecho célebre entre los griegos; en segundo lugar, el uso de tratados en prosa se conecta expresamente con la actividad científica en la que Pitágoras destacó por encima del resto de los hombres:

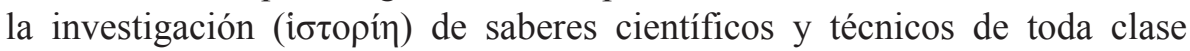
$(\pi \circ \lambda v \mu \alpha \theta i ́ \eta)^{65}$. Es cierto que los testimonios sobre los viajes de Pitágoras a Egipto y Babilonia hacen también verosímil que se sirviera de escritos matemáticos y astronómicos babilonios ${ }^{66}$. Por otro lado, la hipótesis mayoritaria, la de que el Samio bebiese en poemas órficos, tropieza con la dificultad de que, como señala Kahn, es problemático relacionar los escritos órficos con

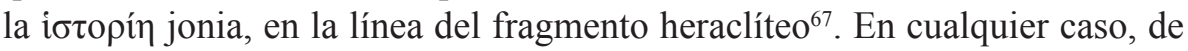
aceptar una influencia oriental —innegable en Pitágoras_- ésta habría pasa-

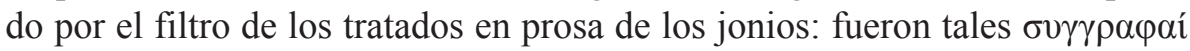
las que suministraron a Pitágoras el material para sus plagios, en opinión de Heráclito.

Se puede intentar llegar más lejos corriendo el riesgo de ser especulativo, un riesgo inevitable cuando se trata de comentar a Heráclito. La expresión heraclítea "sabiduría de su exclusiva propiedad" quizá pueda ser interpretada como una alusión irónica al hecho de que Pitágoras, pese a haberse servido

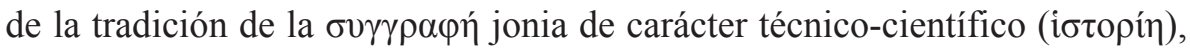

${ }^{65}$ Esta hipótesis (Ch. H. Kahn 1983, pp. 111-112) me parece especialmente sugerente y bien fundamentada en un análisis semántico del vocablo $\sigma v \gamma \gamma \rho \alpha \varphi \eta ́$. No comparto en este fragmento la interpretación de A. García Calvo 1985, pp. 87-89, fundada en una puntuación del texto bastante discutible.

${ }^{66}$ Cf. M. Marcovich 1978, pp. 46-49, que recoge la bibliografía esencial sobre el problema. Al adoptar esta postura, M. Marcovich se adhiere a la tesis de Wilamowitz y von Fritz, mientras que la mayoría de los estudiosos sigue la antigua hipótesis, renovada recientemente por Burkert, de que los escritos usados por Pitágoras eran tratados órficos.

${ }^{67}$ Ch. H. Kahn 1983, p. 114 y n. 9. 
trasplantó a Occidente estos saberes matemáticos como si fuesen patrimonio secreto de su secta, objeto de iniciación filosófica fraudulenta - idea implí-

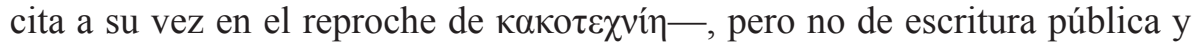
abierta a los interesados en estos saberes. Así, este fragmento nos ofrecería la ridícula imagen de un Pitágoras guardando celosamente para sí y para sus discípulos una sabiduría que era patrimonio común tanto de los grupos profesionales e intelectuales como de las élites políticas de Jonia; es decir, transmitiendo, bajo el secreto de una sabiduría personal no escrita, el contenido de una selección de textos escritos que, probablemente, o circulaban en medios profesionales o habían sido publicados en el sentido específico que a tal acto hemos dado en este trabajo.

La ironía de Heráclito, que es posible rastrear en otro fragmento probablemente antipitagórico (B 35), está hecha desde su convicción en la naturaleza

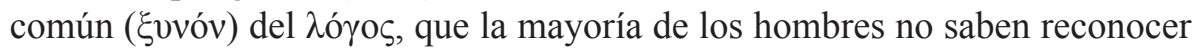
ni en las palabras ni en las acciones que tejen su vivir cotidiano (B 1). Este

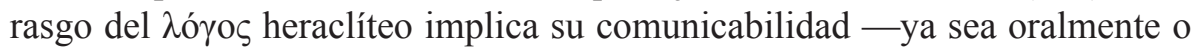
por escrito-, frente a la reserva comunicativa de Pitágoras.

Si avanzamos un poco más en esta idea, podríamos parangonar el fragmento recién comentado con el fr. B 95, y ello pese a las dudas planteadas sobre su extensión exacta.

\section{B 95 (García Calvo 28)}

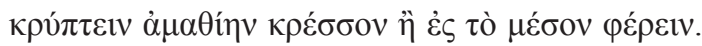

Mejor esconder la ignorancia que llevarla al medio.

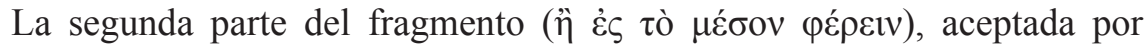
Schleiermacher y Gomperz, está atestiguada en Estobeo y, de forma tergiversada, en Plutarco ${ }^{68}$. Tal como la transmite Estobeo, da la impresión, reforzada por la estructura yámbica del fragmento (3ia), de ser más bien una continuación tardía. Como apunta García Calvo, es cierto que, en la forma rítmica en que lo recoge Estobeo, sería necesario atribuírselo no a Heráclito, sino a Escítino de Teos, un poeta del s. IV a. C. que compuso en yambos una versificación del $\lambda$ ó ${ }^{\circ} \varsigma$ heraclíteo. Sin embargo, el propio García Calvo reconoce que, por la fidelidad con que suele recoger Estobeo otras citas de Heráclito

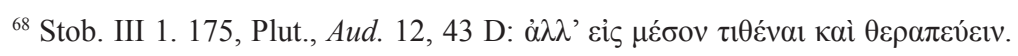


y por la tergiversación de la segunda parte tal como aparece en Plutarco, no sería descabellado suponer que este fragmento se encontrara formulado en el libro de Heráclito en una versión no muy diferente ${ }^{69}$.

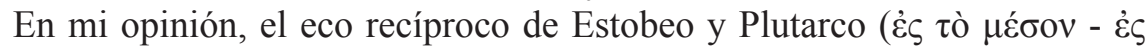

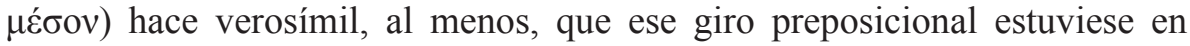
el libro de Heráclito. Así, el fragmento podría ser un nuevo dardo irónico dirigido contra el secreto de la escuela pitagórica, situado no muy lejos del recién comentado B 129: Pitágoras construyó un saber privado y secreto, sólo para iniciados, pero para ello utilizó escritos de geometría y/o tratados de prosa científica, que eran ya entonces patrimonio común de los sabios jonios. Pero es mejor, añade Heráclito con humor y acidez ${ }^{70}$, que la ignorancia de

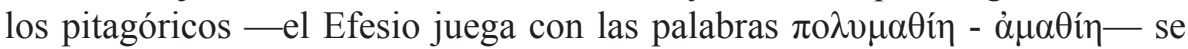

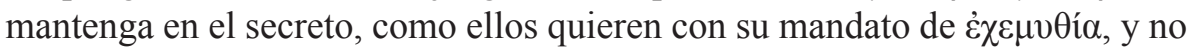
se proclame "en el medio", como las leyes y las decisiones de la Asamblea, y - de forma implícita - como aquellos tratados publicados por los jonios que fueron extractados por Pitágoras (B 129).

Si esta interpretación es verosímil, y hubiera una conexión entre ambos fragmentos, encontraríamos en Heráclito, aplicada de forma indirecta a la publicación escrita de los primeros tratados en prosa -así lo sugiere el

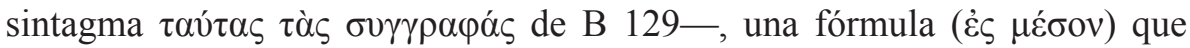
tradicionalmente se había utilizado en el ámbito de la política. Esta expresión, en efecto, podía referirse a la comunicación oral de un mensaje o discurso en el espacio central de la asamblea ${ }^{71}$ o de las audiencias del Gran Rey ${ }^{72}$, sometiéndose así al escrutinio público. Pero lo que más importa a nuestro

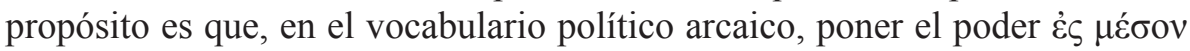
significaba instaurar regímenes isonómicos, es decir, situar en el espacio central de la ciudad (el templo o el ágora) leyes iguales para todos ${ }^{73}$. De esta manera, en el fragmento analizado Heráclito se pronunciaría sesgadamente sobre el simbolismo ético-político que para él encerraba el acto de publicar

\footnotetext{
${ }^{69}$ D. L. IX 16. Cf. A. García Calvo 1985, pp. 92-94.

${ }^{70}$ Los rasgos de humor e ironía son una de las constantes estilísticas explotadas por Heráclito en su crítica de la tradición poética y científica de los griegos (cf. B 35, B 40, B 56, B 57), así como en las tensas relaciones que mantuvo con los efesios (cf. B 121, B 125 A).

${ }^{71}$ Hdt. I 206, III 62, III 83, IV 67, VII 8.

${ }^{72}$ Hdt. III 130 (Darío-Democedes), III 140 (Darío-Silosonte).

${ }^{73}$ Hdt. III 80: Ótanes defiende el régimen isonómico entre los persas; III 142-143: Meandrio y la fallida isonomía de los samios tras la muerte de Polícrates; IV 161: Bato y las prerrogativas regias en Cirene; VII 164: la renuncia de Cadmo a la tiranía en Cos.
} 
por escrito el contenido de las enseñanzas que, a lo largo de su vida, habría ido exponiendo en sucesivas lecturas públicas hasta cristalizar en el libroofrenda del santuario de Ártemis. En torno a este templo giraba el espacio público de las instituciones efesias y en este templo fue consagrado, igual que las leyes de la ciudad, el libro de Heráclito, la expresión más alta de la Ley divina, que otorga sentido a todas las leyes humanas ${ }^{74}$.

3.2. Pero al confiar su tratado en prosa a la protección de Ártemis, Heráclito no sólo reivindicaba simbólicamente para su obra el prestigio y la autoridad asociados a la publicación de las leyes en los templos arcaicos, sino que además proporcionaba al libro, como texto escrito, una autonomía parecida a la de las leyes expuestas en los espacios sagrados, que, al ser protegidas por los dioses de la ciudad, se convertían en marco de referencia abstracto del ejercicio del poder y de la convivencia cívica ${ }^{75}$. Esa autonomía y objetivación del tratado en prosa, que ciertamente es punto de partida de una transmisión y difusión posterior, obedecía en Heráclito a su convicción en la naturaleza objetiva y universal (común) del discurso ( $\lambda$ ó ${ }^{\circ}$ s), cuyo vehículo material era el libro. Ello permite explicar también la consagración del libro según pautas inherentes al pensamiento de Heráclito.

Como tantas otras ofrendas consagradas en los templos de Grecia, la dedicación convertía al libro en un exvoto digno de ser custodiado y celosamente guardado en el tesoro del santuario ${ }^{76}$. Es improbable que el libro de Heráclito como tal estuviera expuesto a la vista de los visitantes del Artemisio, como sí lo estaban en cambio las leyes publicadas en la mayor parte de los templos griegos, que se exhibían en los espacios sagrados transitados por los ciudadanos o se grababan en los muros del edificio ${ }^{77}$.

En esta dirección parece apuntar, por lo demás, el testimonio de Diógenes Laercio, cuando afirma que tanto la oscuridad intencionada de la lengua hera-

\footnotetext{
${ }^{74}$ A mi juicio, en el caso de Heráclito este gesto político, si tuvo lugar en una etapa avanzada de su vida (o al menos después del destierro de Hermodoro, como demuestra B 121) constituiría una especie de desafío y cuestionamiento de la situación política de su ciudad natal, gobernada entonces por un sistema de gobierno - la democracia - abiertamente rechazado por él (cf. supra, 2.5). Esta hipótesis cuadraría con el sentido general de las anécdotas semilegendarias que la biografía de Diógenes Laercio relata acerca de un "retiro político" de Heráclito y de su rechazo furibundo del sistema de gobierno de Éfeso (D.L. IX 3).

${ }^{75}$ Cf. K.-J. Hölkeskamp 1992, pp. 100-102.

${ }^{76}$ Ch. H. Kahn 1979, p. 2 y n. 4.

${ }^{77}$ M. Detienne 1989b (1988), pp. 17-18.
} 
clítea como el depósito del libro en el templo obedecían a una voluntad consciente de hurtar el libro al desprecio del pueblo y de hacerlo sólo accesible a quienes pudiesen comprenderlo ${ }^{78}$. Pese a que este juicio de intenciones, tomado a la letra, difícilmente puede sostenerse en pie, es posible que encierre una sugerencia interesante para nuestro propósito, y es la de presentarnos a un Heráclito preocupado por el uso que pudiera hacerse de su obra, cuando, una vez muerto, escapara definitivamente a su control. Que ésta era una de sus obsesiones permanentes cuando todavía conservaba un control directo sobre su discurso, ya por medio de las lecturas públicas que, según se desprende de los fragmentos, realizó ante sus conciudadanos, ya por medio de la escritura del libro, lo demuestra una de sus paradojas más recurrentes, que aparece ya en el proemio (B 1) pero resuena con fuerza en otros fragmentos: pese a que el $\lambda$ ó $\gamma$ o — esto es, el discurso de Heráclito como expresión lingüística del principio universal por el que se rigen todas las cosas- es "común", los hombres no le prestan oído, $\mathrm{y}$, aunque están en contacto directo y familiar con aquél (B 72), se comportan como si tuvieran un pensamiento particular (B 2), como si se encerrasen en un mundo privado (B 89). De estos y otros fragmentos preocupados por las condiciones de comunicación y percepción intuitiva del $\lambda$ ó $\gamma o \varsigma$ entre los hombres ${ }^{79}$, es posible extraer algunas reflexiones, con las que trato de fundar la dedicación votiva del libro de Heráclito en factores intrínsecos a su propio sistema de pensamiento, y que se superponen a la significación simbólica y política arriba defendida.

En efecto, el lenguaje de Heráclito, al ser $\lambda o ́ \gamma o \varsigma$ hablando de sí mismo, refleja en su propia estructura el principio de estructuración de las cosas: la identidad de los opuestos, que unifica las tensiones contrarias de las fuerzas que constituyen el mundo, se refleja necesariamente en la estructura paradójica de gran parte de los fragmentos que nos han llegado. De ahí la conciencia de estilo de Heráclito: los juegos de palabras, las asonancias, los paralelismos y quiasmos, la ambigüedad sintáctica, el tono oracular de los fragmentos son recursos artísticos mediante los cuales el discurso de Heráclito transparenta la estructura de las cosas. En un lenguaje que avanza mediante un movimiento de contrarios conectados por tensiones opuestas, es natural imaginarse a Heráclito velando por la autenticidad de su discurso. En este sentido, la consagración es un procedimiento para asegurar la lapidaria permanencia del

78 Cf. supra, n. 58.

${ }^{79}$ E. A. Havelock 1966, p. 57. 
lenguaje heraclíteo en una forma escrita y autónoma, a salvo de las fluctuaciones de la transmisión oral-aural ${ }^{80}$.

El fragmento B 92, en que Heráclito describe admirativamente el lenguaje «sin risa, sin adornos y sin perfumes» de la Sibila, termina con una declaración iluminadora de nuestro enfoque de la cuestión: «alcanza con la voz los mil años gracias al dios» ${ }^{81}$. Una vida longeva era lo que perseguía Heráclito para su voz, encerrada en el libro, cuando la confió a la custodia de Ártemis efesia. Precisamente, el parangón que Heráclito establece entre su propio lenguaje y el del Apolo délfico (B 93) ${ }^{82}$, útil para la valoración de su estilo "oracular", convierte al de Heráclito en un tipo de discurso entroncado más

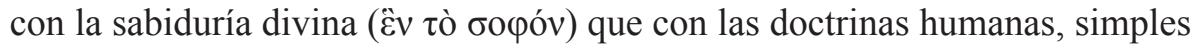
«juegos de niños» (B 70).

Heráclito era plenamente consciente de la relativa soledad de su pensamiento en el marco de la especulación presocrática. Ni los maestros de sabiduría que lo han precedido, a los que critica sin excepción, ni ninguno de sus contemporáneos ha visto la Ley divina que gobierna el mundo, expresada en el $\lambda$ ó $o \varsigma$ de Heráclito. Dios es noche-día, invierno-verano, guerra-paz, saciedad-hambre (B 67), vida-muerte (Dioniso-Hades: B 15). ¿Qué salida tenía el maestro de Éfeso sino dedicar a la divinidad el $\lambda$ ó $\gamma$ o $\varsigma$ eterno, el discurso universal que, para decir y decirse con sentido, ha de anclar sus raíces en la única Ley divina de donde se nutren todas las leyes humanas (B 114)? Profeta de la Ley divina, el discurso común de Heráclito se petrifica como escritura una vez que es depositado en el Artemisio de Éfeso, del mismo modo que las leyes humanas devienen patrimonio común de la $\pi$ ó $\lambda$ is una vez grabadas en estelas de piedra ${ }^{83}$.

\footnotetext{
${ }^{80}$ En esta dirección apuntan también las atinadas reflexiones de S. Mouraviev 2003, pp. 203-204.

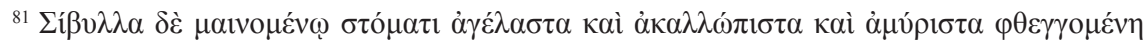

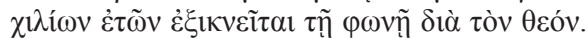

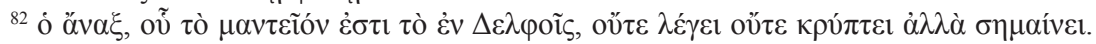

${ }^{83}$ Otros fragmentos heraclíteos, que insisten en la distancia radical entre dioses y hombres (B 78, B 79, B 82, B 83), abonan la sospecha de que el Efesio quería tributar a la divinidad el único $\lambda o ́ \gamma o \varsigma$ que había logrado descifrar la verdadera naturaleza de lo divino y su relación con los hombres. Entre los estudiosos modernos, ha sido Colli (G. Colli 1980, pp. 171-174) quien ha desarrollado de manera más lúcida esta línea hermenéutica. En cambio, me parece inapropiada la propuesta de parangonar el libro de Heráclito con los "discursos sagrados" órfico-pitagóricos (cf. R. Mondolfo-L. Tarán 1972, p. 27), pues ello contradiría las actitudes abiertamente críticas de Heráclito hacia las manifestaciones sobresalientes de la vida religiosa y espiritual de su época: círculos pitagóricos (B 129: cf. supra, III.3.1), cultos orgiásticos
} 


\section{BiBLIOGRAFÍA}

Asper, M. 2004: «Law and Logic. Towards an Archaeology of Greek Abstract Reason», AION 26, pp. 73-94.

Bernabé, A. 1979: «Los filósofos presocráticos como autores literarios», Emerita 47, pp. 357-394.

Braccesi, L. 1982: «Las tiranías y los desarrollos políticos y económico-sociales», en R. Bianchi Bandinelli (ed.), Historia y civilización de los griegos. II. Orígenes y desarrollo de la ciudad. El arcaísmo (Storia e civiltà dei greci. II. Origini e sviluppo della polis. L'arcaismo, Milán 1982), trad. esp., Barcelona, pp. 11-63.

Bremmer, J. N. 1994: Greek Religion, Oxford.

Bollack, J. - Wismann, H. 1972 (= BW): Héraclite ou la séparation, París.

Caballero, R. 2005a: «Reflexiones sobre el concepto de "publicación" en la Grecia Arcaica: el problema de los tratados en prosa», Estudios Clásicos 127, pp. 7-22.

— 2005b: «Libros y lectores en la Grecia arcaica: de Homero a los prosistas jonios», en J. F. Martos Montiel - C. Macías Villalobos (eds.), Studia Varia in Memoriam Salvador Claros, Málaga, pp. 21-31.

Capizzi, A. 1979: Eraclito e la sua leggenda. Proposta di una diversa lettura dei frammenti, Roma.

- 1982: La repubblica cosmica. Appunti per una storia non peripatetica della nascita della filosofia in Grecia, Roma.

Colli, G. 1978: La sapienza greca. II. Epimenide, Ferecide, Talete, Anassimandro, Anassimene, Onomacrito, Milán.

- 1980: La sapienza greca. III. Eraclito, Milán.

Conche, M. 1986: Héraclite. Fragments. Texte établi, traduit, commenté par..., París.

Detienne, M. (ed.) 1989a: Sapere e scrittura in Grecia (Les savoirs de l'écriture en Grèce Ancienne, Lille, 1988), trad. it., Roma-Bari.

- 1989b: «Lo spazio della pubblicità: i suoi operatori intellettuali nella città», en Detienne 1989a (1988), pp. 5-49.

Diano, C. - Serra, G. 1980: Eraclito. I frammenti e le testimonianze, Milán.

Diels, H. - Kranz, W. $1951^{6}$ (= DK): Die Fragmente der Vorsokratiker. Erster Band, Berlín.

(cuyos aspectos rituales, aun reconociendo que expresan una verdad profunda, critica en $\mathrm{B}$ $14,15)$, ritos de purificación (B 5), súplicas a los dioses (B 128). Todo ello autorizaría, en mi opinión, a suponer en Heráclito una posición parecida en relación con las sectas órficas, tan influyentes en la religiosidad de su tiempo (y a veces en el lenguaje mismo de Heráclito), y a negar verosimilitud a los intentos de reconstruir una escatología en el pensamiento del Efesio, en parte similar a la órfica (cf., por ejemplo, W. K. C. Guthrie 1984 [1962], pp. 452-453). 
Gagarin, M. 2003: «Letters of the Law: Written Texts in Archaich Greek Law», en H. Yunis (ed.), Written Texts and the Rise of Literate Culture in Ancient Greece, Cambridge, pp. 59-77.

García Calvo, A. 1985: Razón común. Edición crítica, ordenación, traducción y comentario de los restos del libro de Heraclito, Madrid.

García Quintela, M. V. 1992: El rey melancólico. Antropología de los fragmentos de Heráclito, Madrid.

Guthrie, W. K. C. 1984: Historia de la filosofía griega. I. Los primeros presocráticos y los pitagóricos (A History of Greek Philosophy. I. The Earlier Presocratics and the Pythagoreans, Cambridge, 1962), trad. esp., Madrid.

Havelock, E. A. 1966: «Pre-literacy and the pre-Socratics», BICS 13, pp. 44-67.

- 1996, La Musa aprende a escribir. Reflexiones sobre oralidad y escritura desde la Antigüedad hasta el presente (The Muse learns to write. Reflections on Orality and Literacy from Antiquity to the Present, New Haven-Londres, 1986), trad. esp., Barcelona.

Hölkeskamp, K.-J. 1992: «Written Law in Archaic Greece», PCPhS 38, pp. 87-117.

Jacob, Chr. 1989: «Inscrivere la terra abitata su una tavoletta. Riflessioni sulla funzione delle carte geografiche nell' Antica Grecia», en Detienne 1989a (1988), pp. 151-178.

Jaeger, W. 1962²: Paideia: los ideales de la cultura griega (Paideia: Die Formung des griechischen Menschen: Berlín, 1936²), trad. esp., México - Madrid - Buenos Aires.

- 19822: Alabanza de la ley. Los orígenes de la filosofia del derecho y los griegos (Praise of Law. The Origins of Legal Philosophy, Nueva York, 1947), trad. esp., Madrid.

Kahn, Ch. H. 1979: The art and thought of Heraclitus. An edition of the fragments with translation and commentary, Cambridge.

- 1983: «Philosophy and the Written Word: Some Thoughts on Heraclitus and the Early Greek Uses of Prose», en Robb 1983a, pp. 110-121.

Kirk, G. S. - Raven, J. E. (= KR) 1970: Los filósofos presocráticos. Historia crítica con selección de textos (The Presocratic Philosophers. A Critical History with a selection of texts, Cambridge, 1966), trad. esp., Madrid.

Laks, A. 2001: «Écriture, prose, et les débuts de la philosophie grecque», Methodos, 1, pp. 131-151.

Lledó, E. 1994: «La lucha por la ley (Heráclito, fragmento B 44)», en Lledó, E., Memoria de la ética, Madrid, pp. 254-268.

Marcovich, M. 1978: Eraclito. Frammenti. Introduzione, traduzione e commento a cura di..., Florencia.

Mazzarino, S. 1989²: Fra Oriente e Occidente. Ricerche di storia greca arcaica, Milán (Milán, 1947). 
Mondolfo, R. - Tarán, L. 1972: Eraclito. Testimonianze e imitazioni, a cura di..., Florencia.

Mouraviev, S. 2003: Heraclitea, III 1. Héraclite d'Éphèse. Les vestiges. 1. La vie, la mort et le livre d'Héraclite, Sankt Augustin.

Nieddu, G. F. 1984: «Testo, scrittura, libro nella Grecia arcaica e classica: note e osservazioni sulla prosa scientifico-filosofica», $S \& C$ 8, pp. 213-261.

Robb, K. (ed.) 1983a: Language and Thought in Early Greek Philosophy, La Salle, Illinois.

- 1983b: «Preliterate Ages and the Linguistic Art of Heraclitus», en Robb 1983a, pp. 153-206

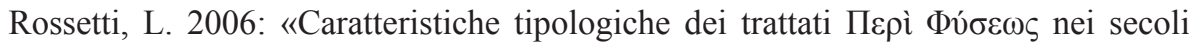
VI-V a.C.», Nova Tellus 24, pp. 113-146.

Sassi, M. ${ }^{a}$ M. 2006: "Anassimandro e la scrittura della "legge" cosmica», en $\mathrm{M}^{\mathrm{a}} \mathrm{M}$. Sassi (ed.), La costruzione del discorso filosofico nell'età dei Presocratici. The Construction of Philosophical Discourse in the Age of the Presocratics, Pisa, pp. 3-26.

Schmidt, W.-Stählin, O. 1929 (= GGL): Geschichte der griechischen Literatur. I, Múnich.

Schottlaender, R. 1965: «Heraklits angeblicher Aristokratismus», Klio 43, pp. 2329.

Thomas, R. 1992: Literacy and Orality in Ancient Greece, Cambridge - Nueva York - Melbourne.

Vernant, J. P. 1986': Los orígenes del pensamiento griego (Les origines de la pensée grecque, París, 1962), trad. esp., Buenos Aires.

Zeller, E. - Mondolfo, R. 1961: La filosofia dei Greci nel suo sviluppo storico. I. I Presocratici; IV. Eraclito (Die Philosophie der Griechen in ihrer geschichtlichen Entwicklung, Leipzig, Reisland, 1892), ed. it., Florencia. 